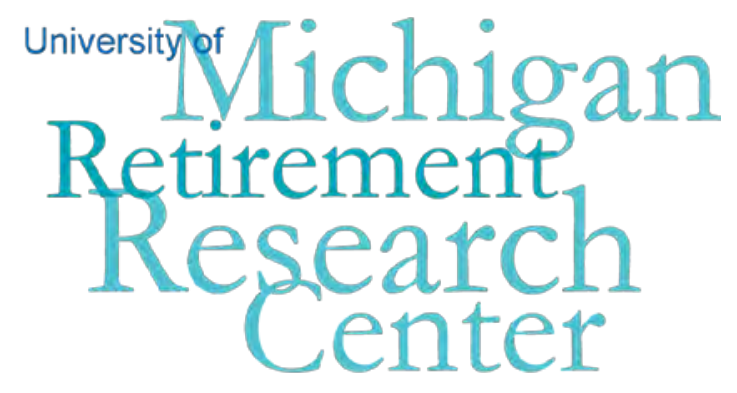

Working Paper

WP 2009-219

\title{
Participation and Contributions in Tax-deferred Retirement Accounts: Evidence from Social Security Records
}

Marjorie Honig and Irena Dushi

\begin{tabular}{|l|l|}
\hline $\mathrm{M}$ & $\mathrm{R}$ \\
\hline $\mathrm{R}$ & $\mathrm{C}$ \\
\hline
\end{tabular}$\quad$ Project \#: UM09-13 



\title{
Participation and Contributions in Tax-deferred Retirement Accounts: Evidence from Social Security Records
}

\author{
Marjorie Honig \\ Hunter College and CUNY \\ Irena Dushi \\ Social Security Administration \\ January 2010 \\ Michigan Retirement Research Center \\ University of Michigan \\ P.O. Box 1248 \\ Ann Arbor, MI 48104 \\ http://www.mrrc.isr.umich.edu/ \\ (734) 615-0422
}

\section{Acknowledgements}

This work was supported by a grant from the Social Security Administration through the Michigan Retirement Research Center (Grant \# 10-M-98362-5-01). The findings and conclusions expressed are solely those of the author and do not represent the views of the Social Security Administration, any agency of the Federal government, or the Michigan Retirement Research Center.

\section{Regents of the University of Michigan}

Julia Donovan Darrow, Ann Arbor; Laurence B. Deitch, Bingham Farms; Denise Ilitch, Bingham Farms; Olivia P. Maynard, Goodrich; Andrea Fischer Newman, Ann Arbor; Andrew C. Richner, Grosse Pointe Park; S. Martin Taylor, Gross Pointe Farms; Katherine E. White, Ann Arbor; Mary Sue Coleman, ex officio 


\title{
Participation and Contributions in Tax-deferred Retirement Accounts: Evidence from Social Security Records
}

\begin{abstract}
Social Security Administration W-2 records contain employee annual tax-deferred contributions for 1990-2003 and sufficient information to calculate tax-deferred contributions for 1984-1989. We use this information to compare tax-deferred contribution profiles of three cohorts of respondents in the Health and Retirement Study to determine whether younger cohorts saved relatively more at the same stage of the life cycle than had older cohorts. We find that participation in tax-deferred retirement plans increased substantially for all cohorts from 1984 to 2003, and that respondents in more recent cohorts were more likely to participate in such plans than respondents of the same ages in the earliest cohort. Their contributions as a percent of earnings were not significantly larger than those of the earliest cohort, however. Despite the increased availability of these employer-provided plans throughout this period, participation rates and contribution amounts remained low among respondents in the lower half of the earnings distribution.
\end{abstract}




\section{Participation and Contributions in Tax-deferred Retirement Accounts: Evidence from Social Security Records}

\section{Introduction}

The shift in recent decades from defined benefit to defined contribution plans has been well documented. Using U.S. Department of Labor data, Buessing and Soto (2006) report that among workers covered by pension plans, the proportion of those covered solely by a defined contribution plan increased from 17 percent in 1980 to 58 percent in 1999. Facilitated by statutory increases in contribution limits to DC plans, overall contributions to such plans increased substantially over the same period (Poterba, Venti and Wise, 2008). ${ }^{1}$

Due to this shift in the pension environment, the income available to workers in retirement will increasingly depend on assets accumulated in tax-deferred retirement accounts. Employees covered by these plans who begin contributing early in their working lives, contribute regularly, and do not withdraw money from their accounts, will be able to accumulate sizable account balances by the time they retire. Different birth cohorts of workers are likely to be affected differently by this shift in the pension environment, however. More recent cohorts, who have spent more of their working lives covered under such plans, will have had more time to contribute to their plans and thus are likely to have accumulated larger account balances at a given age compared to earlier cohorts. Other differences across cohorts, such as educational attainment and the proportions of women in the labor force, may also result in cohort differences affecting contribution amounts and patterns of contributions over time.

\footnotetext{
${ }^{1}$ We refer here to all employer-provided tax-deferred contributions plans as defined contribution plans.
} 
Life-cycle saving theory suggests that individuals will save more in the latter part of their working lives when their earnings are higher relative to their consumption needs. We would thus expect to see that both participation in tax-deferred retirement plans (defined here as contributing to a plan in a given year), as well as contribution amounts, would increase with age for any given cohort. We use Social Security W-2 earnings records linked to survey information from the Health and Retirement Study to examine the participation in tax-deferred accounts of three birth cohorts born between 1931 and 1953. We use this information to determine whether recent cohorts were more likely to contribute to plans, and to make larger contributions to their plans, at the same stage of their life cycle than the earliest cohort. We address a number of questions related to participation in tax-deferred retirement plans. Did the three HRS cohorts (born 193641, 1942-47, and 1948-53) differ with respect to their participation and contributions in 1991, 1997, and 2003 when they were of the same ages (50-55)? What trends regarding participation and contributions do we observe over time for each of these cohorts? What are the trends in participation and contributions by age in a given year and by cohorts as each cohort ages? Finally, do we observe different patterns of participation by earnings level?

We find that participation in tax-deferred retirement plans increased substantially from 1984 to 2003 in all cohorts, and that respondents in more recent cohorts were more likely to participate in tax-deferred plans than those of the same ages in the earliest cohort. Their contributions as a percent of earnings were not significantly larger than those of the earliest cohort, however. We also find that despite the increased availability of employer-provided taxdeferred plans throughout this period, participation rates and contribution amounts remained low among respondents in the lower half of the earnings distribution. 
The next section describes previous research using Social Security Administrative data.

The following section discusses our data drawn from the Health and Retirement Study and linked to Social Security administrative records. Section four examines patterns of participation and annual contributions to tax-deferred retirement accounts. The last section summarizes our findings.

\section{Previous Findings using Social Security Administrative Data}

Four recent studies have used data from Social Security Administration (SSA) W-2 records to examine trends in contributions to tax-deferred retirement plans. Cunningham and Engelhardt (2002) use panel data from W-2 records to examine the responsiveness of 401(k) savings to taxation, employer matching, and lifecycle factors among respondents in the original 1992 HRS cohort. They find that, between 1984 and 1991, the proportion of their sample making tax-deferred contributions increased from 45 percent to 69 percent. Over the same period, the median contribution among those with positive contributions increased from $\$ 1,350$ to $\$ 1,854$, and the mean contribution as a percent of earnings increased from 5.6 percent to 7.3 percent. Their estimates also indicate that older workers on average had larger tax-deferred contributions and that there was an upward trend in annual 401(k) contributions over this period.

Pattison and Waldron (2008), using data from a 0.1 percent sample of the overall SSA Master Earnings File on the entire working population, examine trends between 1990-2001 in tax-deferred contributions. They find that the proportion of workers making contributions, as well as contributions rates, increased at all earnings levels over this period, but that the increase was smaller among low-earnings workers. They also find that, in all three selected years (1990, 1995, 2001), the participation rate increases with age up to the mid-50s and then declines for 
both men and women. Smith, Johnson and Muller (2004) link SSA administrative data to respondents in the 1996 panel of the Survey of Income and Program Participation (SIPP) to examine tax-deferred contributions over time. Their findings indicate that between 1990 and 2001, on average 27 percent of workers ages 20-69 contributed to tax-deferred retirement accounts and that the participation rate increased with age up to the late fifties and then declined. They also find that the annual contribution amount increased with age from less than $\$ 2,000$ for respondents in their twenties to about $\$ 4,500$ for those in their fifties and sixties, and that the median contribution rate (contributions as a percent of earnings) also increased with age from about four percent for those in the early stages of their working life to about eight percent for those in their sixties.

Kawachi, Smith, and Toder (2005) use W-2 records linked to SIPP data from the 1992, 1996 and 2001 panels to examine trends in the shares of employees ages 20-69 who contributed the legal maximum to their defined contribution accounts as statutory contribution limits increased over time. They find that the percentage of workers who contributed the maximum amount increased between 1990 and 2003 from 3.5 to 7.5 percent and that workers ages 50 and older were more likely to contribute the maximum than workers under the age of 30 . In addition, workers in a given birth cohort were more likely to contribute the maximum as they aged and, at a given age, workers in more recent cohorts were more likely to contribute the maximum than workers in earlier birth cohorts

\section{Data}

Our sample is drawn from the Health and Retirement Study, a longitudinal, nationally representative survey of older Americans over the age of 50 and their spouses of any age. The 
first wave of interviews was conducted in 1992 and follow-up interviews were conducted every other year thereafter. In this analysis we restrict our samples to survey respondents born in 1931-53 consisting of three cohorts: the original HRS cohort born 1931-41 and first interviewed in 1992, the War Babies (WB) cohort born 1942-47 and first interviewed in 1998, and the Early Baby Boomers (EBB) cohort born 1948-53 and first interviewed in 2004.

An important feature of the data is that respondents in each of these cohorts were asked in their first interview (either in 1992, 1998, or 2004) to give permission for their Social Security benefits and earnings records to be linked to their survey information. ${ }^{2}$ Respondents in the HRS cohort were asked for permission to release their records again in 2004 regardless of whether they had given consents in 1992. This approach was undertaken in order to obtain consents not only from those who had initially refused to release their records in 1992 but also to update the earnings and benefits records up to year 2003 for those who had given earlier consents. In the WB cohort, only respondents who initially refused to release their records were asked again in 2004. These later consents resulted in a near doubling of the HRS and WB cohort samples with information on tax-deferred contributions. Members of the EBB were asked to give consents when they entered the survey in 2004. Appendix Table 1 indicates the sizes of samples of respondents in each birth cohort when they were first interviewed and the proportions of those who consented to the release of their Social Security administrative records by permission year. Social Security earnings records contain information from the Internal Revenue Service Form W-2 filed by employers to report salaries and benefits paid to employees. For each job held by a respondent in a given year, the record contains information on the annual compensation subject to federal income taxation (which includes wages, tips and other compensation), the

${ }^{2}$ See Olson (1999) and Mitchell, Olson and Steinmeier (2000) for discussions of these data. The information on Social Security benefits and detailed earnings of respondents who gave permission for the release of their records is available to researchers on a restricted basis only. 
earnings that are subject to the Social Security payroll tax (FICA), referred to as covered or taxable earnings, the earnings that are not subject to FICA (uncovered earnings), the earnings that are subject to Medicare tax, self-employment taxable income, and tax-deferred contributions to employer-sponsored retirement accounts. ${ }^{3}$ As stipulated in the Internal Revenue Code as of 1984, employee contributions (both mandatory and voluntary) to tax-deferred retirement plans are excluded from federal income taxation in the year of contribution, but are subject to the Social Security (FICA) payroll tax. As a consequence, from 1984 to 1989, employers reported both wage earnings with and without tax-deferred contributions in the W-2 form. Thus, employee contributions to tax-deferred retirement plans were not explicitly identified in the W-2 form and therefore did not appear in the earnings records for 1984-1989. For these years, for all respondents in our sample regardless of the consent year, we calculate the annual amount of taxdeferred contributions as the difference between FICA earnings and total compensation. ${ }^{4}$ From 1990, the amount of the tax-deferred contributions is reported in a separate field in the W-2 record. This field is included in the HRS restricted data file for respondents consenting to the release of their records in 1998 and 2004; it is, not included, however, for the 1992 consenters. Thus, for the latter group of consenters, we calculate the annual amount of tax-deferred contributions for 1990 as the difference between FICA earnings and total compensation. ${ }^{5}$ Thus,

\footnotetext{
${ }^{3}$ See Olsen and Hudson (2009), Pattison and Waldron (2008) and Utendorf (1999) for a more detailed discussion of the Social Security administrative data.

${ }^{4}$ See Cunningham and Engelhardt (2002) for a discussion of this calculation. We perform this calculation only for respondents with earnings below the Social Security taxable maximum. Appendix Table 2 indicates the Social Security taxable earnings maximum, the maximum limit of tax-deferred contributions, national average wage, and the median and median of FICA earnings of our overall sample over the period of our study. We exclude respondents whose total compensation in a given year is above the total maximum of Social Security (FICA) earnings because we cannot calculate their tax-deferred contributions. In the Social Security earnings records, FICA earnings are reported up to the Social Security maximum taxable earnings. Among covered workers in the U.S, five to six percent had annual earnings exceeding the Social Security taxable maximum between 1984 and 2003 (Social Security Administration 2007, Table 4.B1).

${ }^{5}$ Prior to 1991, the maximum taxable FICA earnings was the same as the maximum taxable Medicare earnings.

Therefore, one could use either the FICA earnings or the Medicare earnings to calculate the tax-deferred
} 
for 1991 we calculate the amount of tax-deferred contributions as the difference between the Medicare taxable earnings and the total compensation.

Social Security administrative records are available up to the year preceding the year of consent. Our period of analysis thus begins in 1984, the first year a tax-deferred contribution can be calculated, and extends to 2003, the year prior to the most recent consent. Because different cohorts entered the survey at different points in time and gave consents in different years, the years over which we observe participation and contributions to tax-deferred plans vary by cohort and consent year. Thus, for the HRS cohort, we examine contribution histories over the period 1984-1991 for survey respondents consenting in 1992, and over 1984-2003 for those consenting in 2004. For the WB cohort, we examine contributions in 1984-1997 for respondents consenting in 1998 and in 1984-2003 for those consenting in 2004. For the EBB cohort who gave consents when first interviewed in 2004, we examine contributions in 1984-2003. Appendix Table 3 indicates, by year of consent, the years in which tax-deferred contributions are either available or calculated, the years in which detailed earnings records are available, and the periods over which we are able to investigate participation and contribution patterns. Appendix Table 4 indicates the age range of respondents over the period of our study and maps respondents' ages at each interview year by cohort. The ages of our overall sample range from 31-53 in 1984 to 50-72 in 2003.

We merge respondents’ demographic survey information, including birth year, age, gender, race/ethnicity, education, and marital and health status, with the information on their taxdeferred contributions from their Social Security earnings records. ${ }^{6}$ Our samples, for each year

contribution. In 1991, the maximum earnings subject to Medicare taxation was raised to $\$ 125,000$ compared to the Social Security taxable maximum of $\$ 53,400$.

${ }^{6}$ It is worth noting that we cannot determine from the information in the earnings records whether employees' contributions are voluntary or mandatory, or whether the employer matches employee contributions. 
from 1984 to 2003, consists of all HRS survey respondents born 1931-53 for whom W-2 earnings records indicate positive FICA earnings in that year. We exclude respondents who are self-employed and those with uncovered earnings.

Our focus in this investigation is to identify participation in tax-deferred plans among respondents in the Health and Retirement Study. Our outcomes of interest are the participation rate and the annual contribution amount, the latter both in absolute terms and as a percentage of earnings. We define the participation rate for a given year as the proportion of respondents with FICA earnings who made tax-deferred contributions to a defined contribution plan in that year, as reported in their $\mathrm{W}-2$ records. ${ }^{7}$ We calculate the annual median contribution and median contribution rate among respondents making contributions in that year.

We first examine differences among the three HRS cohorts when they were of the same age with respect to each of our outcomes of interest: participation, contributions, and contribution rates. We then compare changes in participation and contributions from 1984-2003 for each of the three birth cohorts. Finally, we examine age and cohort patterns (age profiles for selected years and cohort profiles by age) in these outcomes of interest.

\section{Findings}

\subsection{Differences between cohorts of the same age.}

We first compare participation rates, contributions, and contribution rates (contributions as a proportion of earnings) of respondents in the HRS, WB and EBB cohorts at ages 50-55, their ages one year prior to entry into the HRS survey and the ages for which we have their Social

\footnotetext{
${ }^{7}$ Our participation rate is defined on all employees because we cannot determine from the W-2 record data which employees were offered a tax-deferred plan.
} 
Security records. ${ }^{8}$ Thus, respondents in the original HRS cohort are ages 50-55 in 1991, the WB cohort, ages 50-55 in 1997, and the EBB cohort, ages 50-55 in 2003.

Figure 1a shows participation rates and median contributions for each of the three cohorts, revealing that participation rates among respondents ages 50-55 differed substantially between the three cohorts and time periods. ${ }^{9}$ Respondents in the original HRS cohort were the least likely to participate in tax-deferred retirement plans (31 percent in 1991). Respondents in the WB cohort, however, were more likely to participate (41 percent) than respondents in the later EBB cohort (37 percent). This pattern is also evident with respect to contribution amounts. Respondents in the WB cohort contributed substantially more to their plans than respondents in either the HRS or EBB cohorts. The lower participation rate and smaller contributions of the more recent EBB cohort compared to the earlier WB cohort may be a consequence of the relatively large size of the EBB cohort and the resulting difficulty that members of this cohort faced when they entered the labor market. Figure $1 \mathrm{~b}$ indicates that contributions relative to earnings are nearly identical (about 5.5 percent) in the three cohorts, lending support to the premise that the early labor market disadvantage of the EBB cohort may have had lasting consequences. In all three cohorts, participation rates and median contributions increase with education and earnings (Appendix Table 5). In addition, married respondents, whites, and males are more likely to participate in plans and to make larger annual contributions.

\footnotetext{
${ }^{8}$ If respondents gave consents at the time of their first interview, for example in 1992, their earnings records are available up to the prior year (in this example, to 1991) because the consent form asks for permission to use information for prior years and not for the current or future years.

${ }^{9}$ Figures 1a, 1b, and 2a are based on tabulations in Appendix Table 5, which presents participation rates, median contributions, contribution rates, and median FICA earnings overall and by selected demographic characteristics. The samples consist of respondents in each cohort with positive FICA earnings who were ages 50-55 in the year prior to the interview year.
} 
Figure 2a presents participation rates for each cohort by W-2 earnings categories. ${ }^{10}$ In each cohort, participation rates increase systematically with earnings, starting with rates of about 10 percent at annual earnings under $\$ 20,000$ to rates of 62 to 70 percent for respondents earning $\$ 70,000$ to $\$ 89,999$. At annual earnings of $\$ 90,000$ and above, the participation rates of the WB and EBB cohorts are 78 and 76 percent, respectively. The participation rate of the HRS cohort is 47 percent, which is likely to be an underestimate of the true value. For this cohort, we are unable to calculate the tax-deferred contributions of 27 percent of respondents with annual earnings of $\$ 90,000$ and above, and thus must necessarily define them as non-participants, because their Medicare earnings are less than their annual total compensation. The remaining 26 percent of respondents in this earnings category are correctly defined as non-participants because their Medicare earnings are equal to their total compensation.

Figure 2b shows the distribution of annual W-2 record contributions by cohort among respondents ages 50-55 with positive contributions. In each of the cohorts, the annual contributions of approximately 25 percent of respondents are \$1,000 or less, and an additional 20 percent contribute only $\$ 1,001-\$ 2,000$. About 20 percent of respondents in each of the cohorts contribute $\$ 6,000$ or more. The modal contribution rate in the HRS and WB cohorts is in the four to six percent range; the modal rate for the EBB cohort is in the two to four percent range (Figure 2c).

It is important to note that these observed differences in participation, contributions, and contribution rates between the three cohorts may be due to cohort differences (younger cohorts may be more likely to participate in tax-deferred retirement plans) or to differences over time (tax-deferred plans having become more prevalent in recent years).

\footnotetext{
${ }^{10}$ Appendix Table 6 provides distributions of FICA earnings for each cohort among respondents with positive FICA earnings.
} 


\subsection{Trends over time}

Appendix Table 7 and Figures 3a-c indicate trends in participation rates, median contributions, and median contribution rates for each birth cohort from 1984 to 2003, the years for which tax-deferred contributions are available. Figure 3a indicates a steady increase in participation rates in the WB and EBB cohorts, consistent with the increase in employerprovided defined contribution plans from the early 1980’s throughout the 1990's (Buessing and Soto 2006). The participation rate of respondents in the HRS cohort, however, who were closer to retirement than those in the other two cohorts, remained about 30 percent in the 1990's and declined in the latter years. Figure 3b reveals that median annual contributions in all three cohorts rose in the 1990's and then declined slightly. Figure 3c indicates that contribution rates increased slightly in all three cohorts from the early 1980s to the end of the period. These observed trends are a function of both period effects and the increasing age of respondents in our sample.

Finally, we examine participation rates, median contributions, and median contribution rates by earnings quartiles from 1984 to 2003 (Appendix Table 8 and Figures 4a-c). Figure 4a indicates that participation rates increased over time in the upper earnings quartiles but remained constant among respondents in the lowest two quartiles. The increase among earners in the top earnings decile was particularly sharp in the late 1980s, moderating in the early 1990's, and leveling off thereafter. By 2003, the participation rate in the fourth earnings quartile was approximately 60 percent compared to less than 20 percent in the lower two quartiles. Annual contributions among participants in the lowest three earnings quartiles amounted to $\$ 2,000$ or less per year over this period (Figure 4b). Among respondents in the top earnings quartile, in contrast, annual contributions increased from slightly more than \$2,000 in 1984 to nearly $\$ 6,000$ 
in 2003. More striking is the increase in median annual contributions in the top $10^{\text {th }}$ earnings decile, from \$2,000 in 1984 to nearly \$12,000 (the maximum contribution limit) in 2003. Median contribution rates in the upper three quartiles remained fairly steady over time, with those in the fourth quartile increasing from 4.5 percent to 7 percent (Figure 4c). In contrast, contribution rates of respondents in the lowest earnings quartile increased substantially from the mid-1980's to the early 1990’s, fluctuated throughout the 1990’s, and declined thereafter. These relatively large changes in the contribution rate among respondents in the lowest earnings quartile may reflect changes over time in earnings rather than contributions, as this group may be more likely to move in and out of the labor force in a given year.

\subsection{Age and Cohort Profiles: Cross-section and cohort views}

We now examine our three outcomes of interest (respondents’ participation in taxdeferred plans, their annual contributions, and their contributions relative to their annual earnings) to determine whether there are systematic variations among respondents by age, time period, and cohort. This analysis will reveal whether respondents at different ages in a given year are more or less likely to participate in or contribute to a tax-deferred plan (on the assumption that there are no cohort differences among them), and whether participation rates and contributions of respondents in a given cohort change as they age (assuming they do not change over time). ${ }^{11}$

We first examine differences in outcomes by age and time, assuming there are no cohort differences among the respondents in our sample born 1931-53. Appendix Table 9 and Figures

\footnotetext{
${ }^{11}$ Age, period, and cohort effects cannot be separately identified because they do not vary independently, even in panel data. This identification problem is discussed in a number of contexts in Hobcraft, Menken, and Preston (1982), Hanoch and Honig (1985), MaCurdy and Mroz (1995), Paxton (1996), and Chen, Wong, and Lee (2001), Rentz and Reynolds (1991), and Ameriks and Zeldes (2004).
} 
5a-c indicate participation rates, median contribution amounts, and median contribution rates by age for 1991, 1997, and 2003, the years prior to the first interview in which each cohort entered the survey; to these years, we add 1985, six years prior to this sequence, to reflect these outcomes at earlier ages. The first two symbols in each line in figures 5a-c represent the EBB cohort (the youngest), the next two represent the WB cohort, and the last four represent the HRS cohort (the oldest). Figure 5a indicates that participation rates at given ages have generally increased over time. In other words, at the same age, respondents in later years are more likely, for the most part, to participate in tax-deferred plans than those in earlier years. This pattern may reflect the effect of either period or cohort differences or a combination of both influences. The pattern of participation by age, moreover, has also changed over time. In the earliest years (1985 and 1991), participation initially increased with age but then remained fairly constant through the late fifties. In more recent years (1997 and 2003), participation rates initially increase with age, then decline sharply in the late fifties.

Figure $5 b$ indicates that median annual contributions increase with age up to 59-61 and then decrease, reaching a maximum in the range of $\$ 2,500-\$ 3,000$ per year. At given ages, annual contributions are somewhat larger (in real terms) in more recent years. It is worth noting that contributions in 2003 were smaller than in 1997, possibly reflecting the effect of the 2001 recession. Finally, Figure 5c indicates that median contribution rates increase with age from about four percent of earnings among respondents in their early forties to about seven percent among respondents in their early sixties. It is notable that there was no significant change in contribution rates from 1985 to 2003.

We next partition each of the three Health and Retirement Study cohorts into three-year birth cohorts in order to examine in greater detail the patterns of participation and contributions 
in tax-deferred plans among these cohorts as they age. In the Health and Retirement Study, the original HRS cohort consists of respondents born 1931-41; the WB cohort, respondents born 1942-47; and the EBB cohort, respondents born 1948-53. We divide each of these three original Health and Retirement Study cohorts into smaller cohorts comprised of respondents born in three consecutive birth years. We divide the EBB cohort into two sub-cohorts born 1948-50 and 195153, the WB cohort into two subgroups (1942-44 and 1945-47), and the original HRS cohort into four subgroups (1931-32, 1933-35, 1936-38, and 1939-41). Figures 6a-c and Appendix Tables 10a-c present the participation rates, median contribution amounts, and median contribution rates by cohort as each of these three-year cohorts age.

Figure 6a indicates that the participation rate of each of these cohorts increases as its members age, peaking in their fifties then declining, revealing a hump-shape pattern. This pattern of increased participation most likely reflects the growing popularity of tax-deferred plans over this period, although we cannot disentangle this effect from the increasing age of these cohorts. We cannot, in other words, determine whether the period or age effect is stronger when both influences move in the same direction. In each cohort, participation rates eventually decline with age, suggesting that the age effect becomes stronger than the period effect in the older age range of each cohort. The decline in participation may reflect older workers moving into part-time or lower-paying jobs, thus limiting their opportunities and/or incentives to participate in tax-deferred plans. We also observe that members of more recent cohorts in their mid-fifties have higher participation rates than those of earlier cohorts of the same ages, ranging at ages 53-55 from a rate of about 10 percent in the cohort born in 1931-32 to a rate of 50 percent in the cohort born 1945-47. 
Figure $6 \mathrm{~b}$ indicates that median annual contributions increased for all cohorts as they aged, from about $\$ 1,500$ in their early thirties to about $\$ 3,000$ in their late fifties, after which contribution amounts decline sharply. This observed upward trend in contributions may reflect an age effect (increasing contributions with age) or a period effect (larger contributions as taxdeferred plans became more popular); the two influences cannot be disentangled, however. In contrast to the pattern observed in Figure 6a, cohort lines are nearly indistinguishable, suggesting that there are no substantial differences among cohorts with respect to contribution amounts. Finally, Figure 6c indicates that contribution rates increase only marginally with age, from about four percent in the late thirties to about seven percent in the early sixties. Contribution rates, furthermore, are nearly identical across cohorts, diverging only at ages 65-67. These patterns suggest that, on average, neither period nor age effects are important in determining contribution rates and that respondents, perhaps due to inertia, do not substantially change their contribution rates over their working lives.

\section{Conclusion}

Merging Social Security earnings records with data from the Health and Retirement Study, we find that participation in tax-deferred retirement plans increased substantially in all cohorts from 1984 to 2003. Respondents in the WB cohort were more likely to contribute to a tax-deferred plan than respondents of the same ages in the HRS cohort. However, the participation rate of the EBB cohort was lower than that of the WB cohort, which may reflect their relatively less favorable earnings experience throughout their working life.

Throughout the period of our analysis, while the overall participation rate increased, it remained unchanged at below 20 percent for respondents in the lowest two earning quartiles. 
Furthermore, median annual contributions of those in the lowest three quartiles remained at $\$ 2,000$ or less. In contrast, the participation rate of those in the highest quartile increased from about 20 percent in 1984 to 60 percent in 2003, and the median annual contribution increased from about $\$ 2,000$ to $\$ 6,000$. These findings suggest that respondents in the highest earnings quartile benefited most from the increased availability of employer provided tax-deferred plans.

Our findings also reveal that the pattern of participation by age changed over this period. In the early years, participation rates in these plans initially increased with age but then remained constant through respondents' late fifties. In more recent years, participation rates initially increased with age but then decline sharply in respondents' late fifties. In contrast, median contribution rates increased with age from approximately four percent of earnings among respondents in their early forties to about seven percent among respondents in their early sixties. At the same age, respondents in 2003 were more likely to contribute to tax-deferred plans than in 1984 or 1991, a trend reflecting either a period effect or cohort effect, or both.

Lastly, we find that for each of the three-year birth cohorts, participation rates increase as respondents age up to their mid fifties, the results of both age and period effects, and then declines, suggesting that the age effect becomes more dominant. Furthermore, at any given age, younger cohorts are more likely to participate than older cohorts. Median annual contributions increase for each cohort as it ages from about $\$ 1,500$ when they are in their forties to about $\$ 3,000$ when they are in their late fifties. Moreover, at any given age there are no substantial differences in contribution amounts among cohorts, suggesting the cohort effect may be relatively weak. Notably, contribution rates, ranging from four to seven percent, do not differ by cohort. 


\section{References}

Ameriks, John and Stephen P. Zeldes. 2004. "How Do Household Portfolio Shares Vary With Age?” TIAA-CREF Institute Working Paper 6-120101.

Buessing, Marric, and Mauricio Soto. 2006. “The State of Private Pensions: Current 5500 Data.” Issue in Brief No. 42. Boston, MA: Boston College Center for Retirement Research.

Chen, Renbao, Kie Ann Wong, and Hong Chew Lee. 2001. “Age, Period, and Cohort Effects On Life Insurance Purchases in the U.S.” The Journal of Risk and Insurance, 68(2), 303-327.

Cunningham, Christopher R., and Gary V. Engelhardt. 2002. "Federal Tax Policy, Employer Matching, and 401(k) Saving: Evidence from HRS W-2 Records.” National Tax Journal Vol. LV, No. 3, (September 2002): 617-645.

Hanoch, Giora and Marjorie Honig. 1985. “"True” Age Profiles of Earnings: Adjusting for Censoring and for Period and Cohort Effects," The Review of Economics and Statistics, 67(3), 383-394.

Hobcraft, John, Jane Menken, and Samuel Preston. 1982. "Age, Period, and cohort Effects in demography: A Review,” Population Index, 48(1), 4-43

Kawachi Janette, Karen E Smith, and Eric J. Toder. 2005. "Making Maximum Use of Tax-deferred Retirement Accounts.” Center for Retirement Research at Boston College. WP

MaCurdy, Thomas and Thomas Mroz. 1989 "Measuring Macroeconomic Shifts in Wages from Cohort Specifications,” Mimeo. Department of Economics, Stanford University, Palo Alto.

Mitchell, Olivia S., Jan Olson, and Thomas L. Steinmeier. 2000. "Social Security Earnings and Projected Benefits,” in Olivia S. Mitchell, P. Brett Hammond, and Anna M. Rappaport, eds., Forecasting Retirement Needs and Retirement Wealth (Philadelphia: University of Pennsylvania Press), pp. 327-360.

Olson, Anya and Russell Hudson. 2009. “Social Security Administration’s Master Earnings file: Background Information.” Social Security Bulletin. Vol. 69, No.3: 29-45.

Olson, Janice A. 1999. "Linkages with Data from Social Security Administrative Records in Health and Retirement Study.” Social Security Bulletin, Vol. 62, No. 2: 73-85.

Pattison, David and Hilary Waldron. 2008. "Trends in Elective Deferrals of Earnings from 19902001 in Social Security Administrative Data”. Social Security Administration. ORDP Research and Statistics Note No. 2008-03. www.socialsecurity.gov/policy.

Paxson, Christina. 1996. "Saving and Growth: Evidence from Micro Data," European Economic Review, 40, 155-288. 
Poterba, James, Steven Venti, and David A. Wise. 2008. "The Changing Landscape of Pensions in the United States," in Overcoming the Saving Slump: How to Increase the Effectiveness of Financial Education and Saving Programs, edited by Anamaria Lusardi, pp.17-46. Chicago: The University of Chicago Press.

Rentz, Joseph O. and Fred D. Reynolds. 1991. "Forecasting the Effects of an Aging Population on Product Consumption: An Age-Period-Cohort Framework," Journal of Marketing Research, XXVIII, 355-60.

Smith Karen E., Richard W. Johnson, and Leslie A. Muller. 2004. "Deferring Income in Employer-Sponsored Retirement Plans: The Dynamics of Participant Contributions.” The Urban Institute.

Social Security Administration. 2007. Annual Statistical Supplement to the Social Security Bulletin.

Utendorf, Kelvin R. 1999. "Recent Changes in Earnings Distributions in the United States: Age and Cohort Effects.” Social Security Bulletin, Vol. 62, No. 2:14-29. 


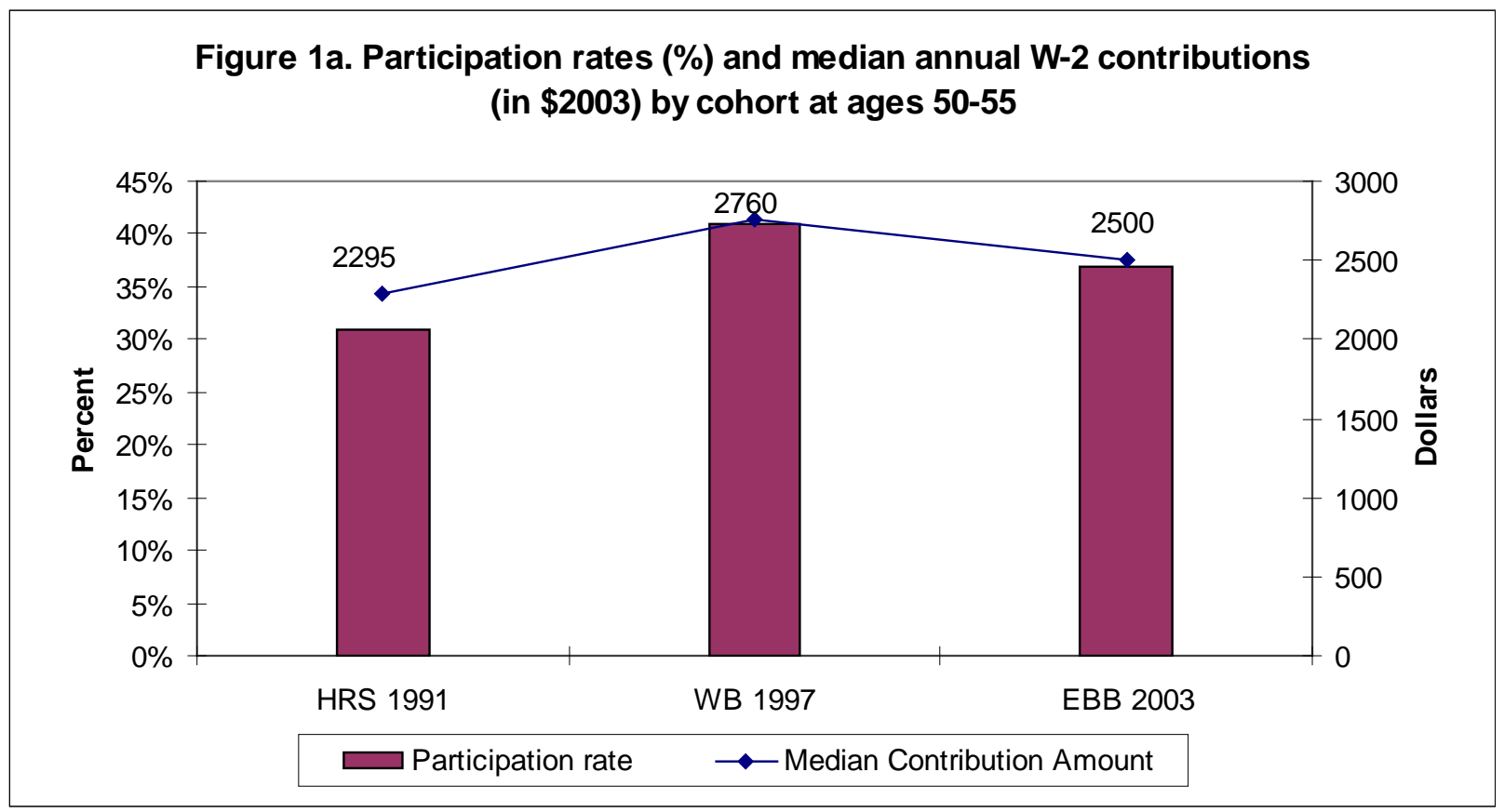

Figure 1b. Median annual W-2 contribution rates by cohort at ages 50-55

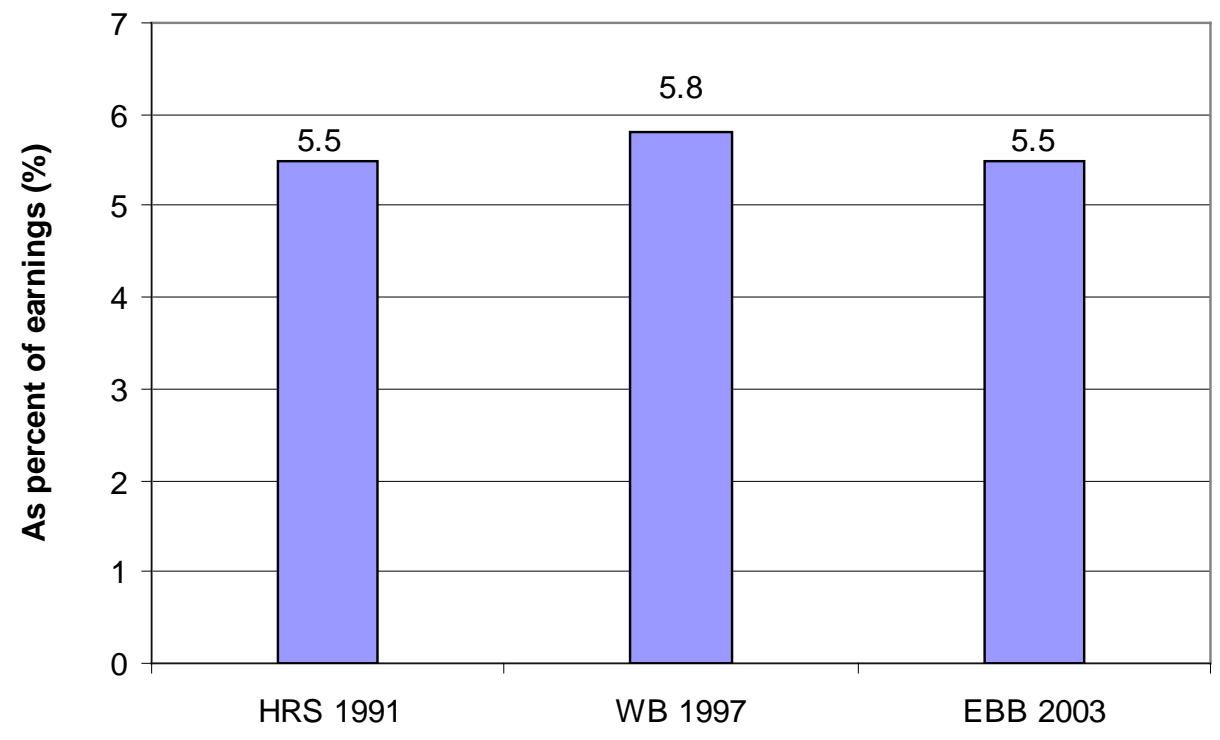



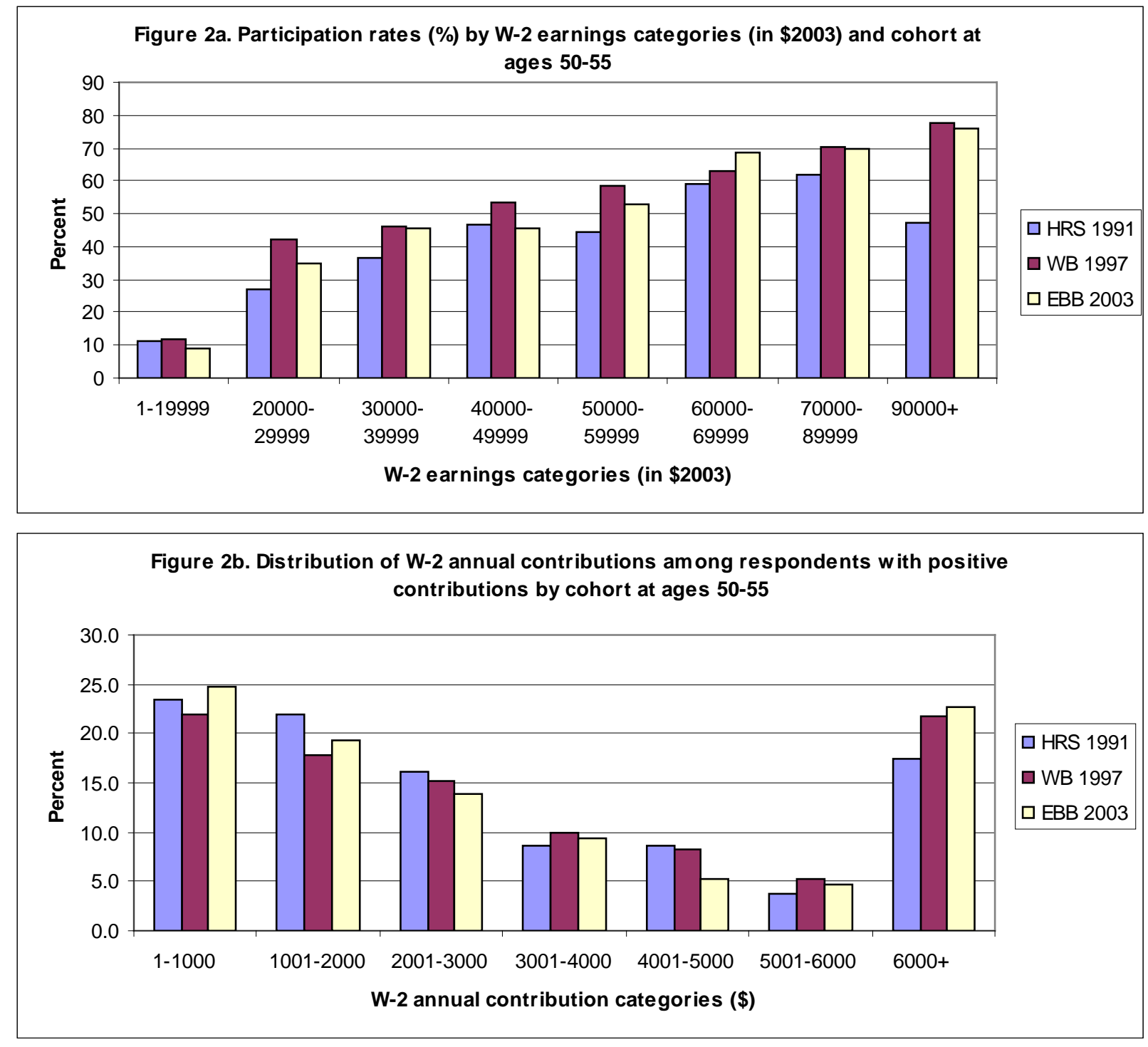

Figure 2c. Distribution of W-2 annual contribution rates among respondents with positive contributions by cohort at ages $\mathbf{5 0 - 5 5}$

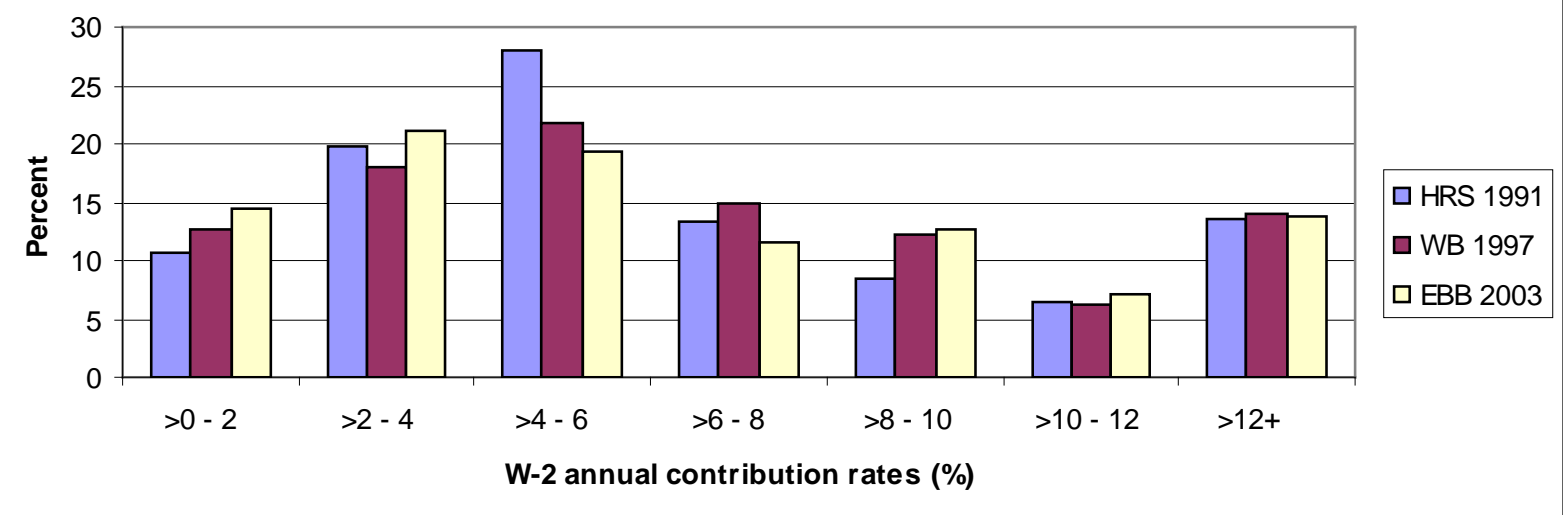



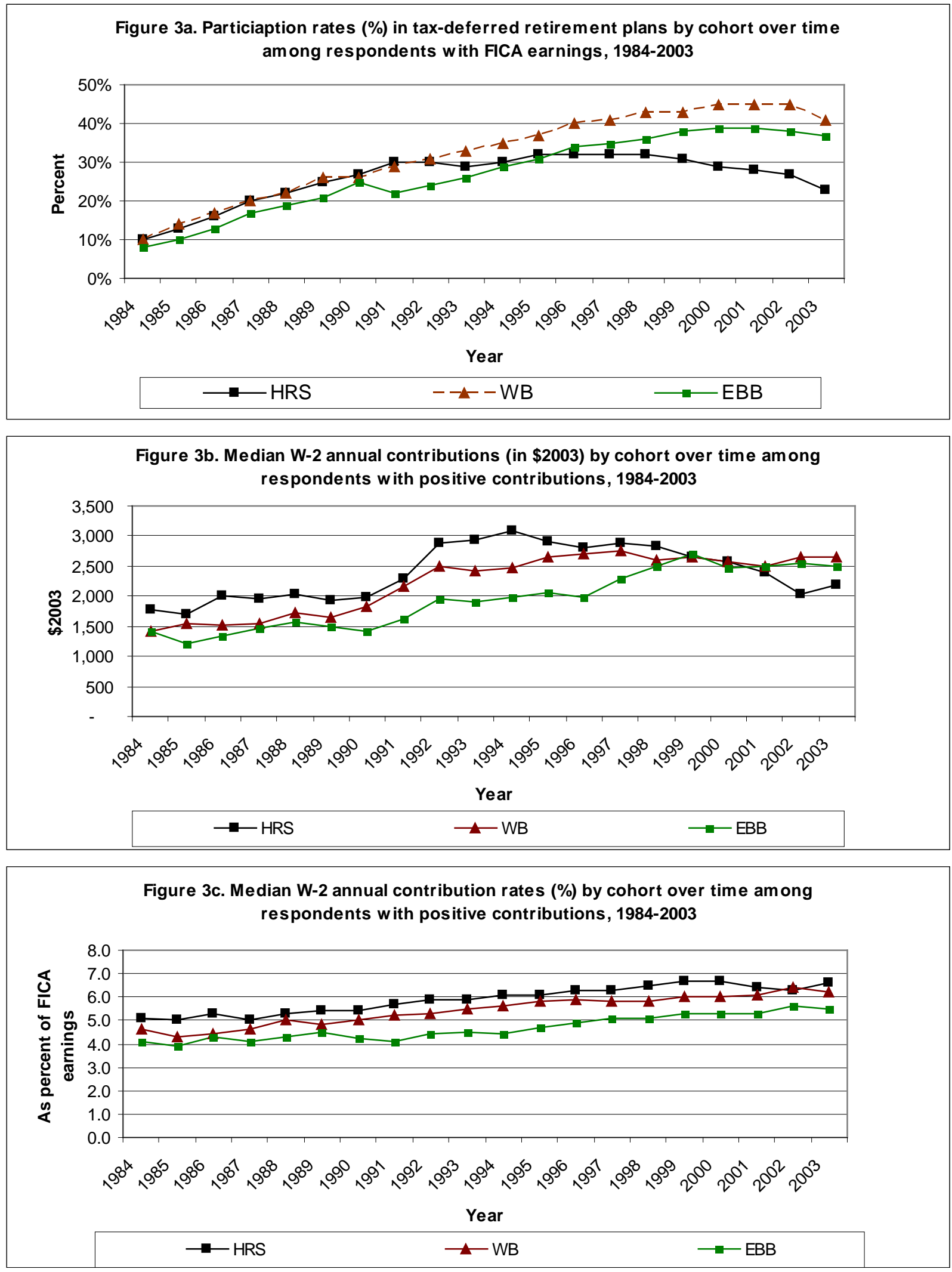

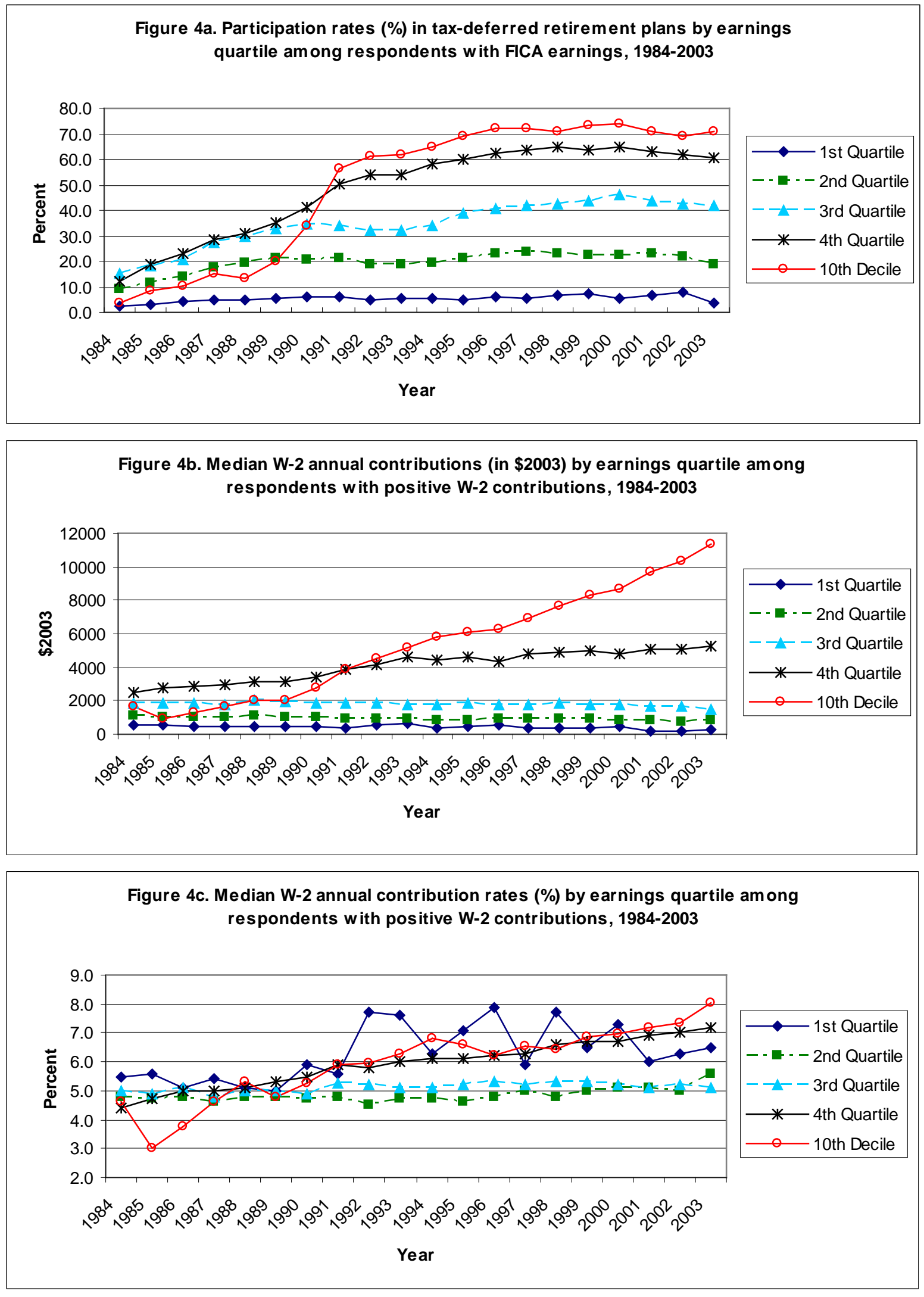

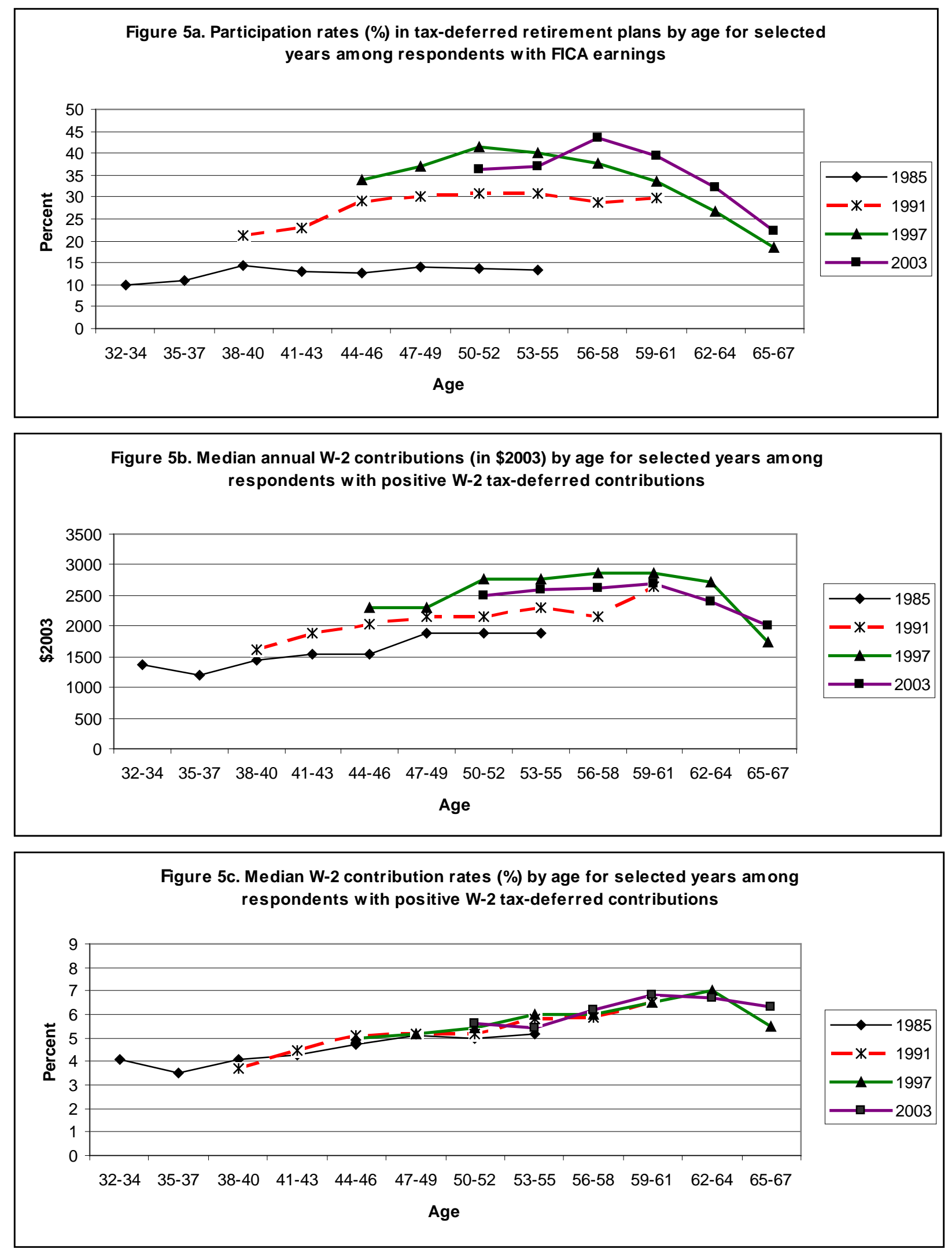

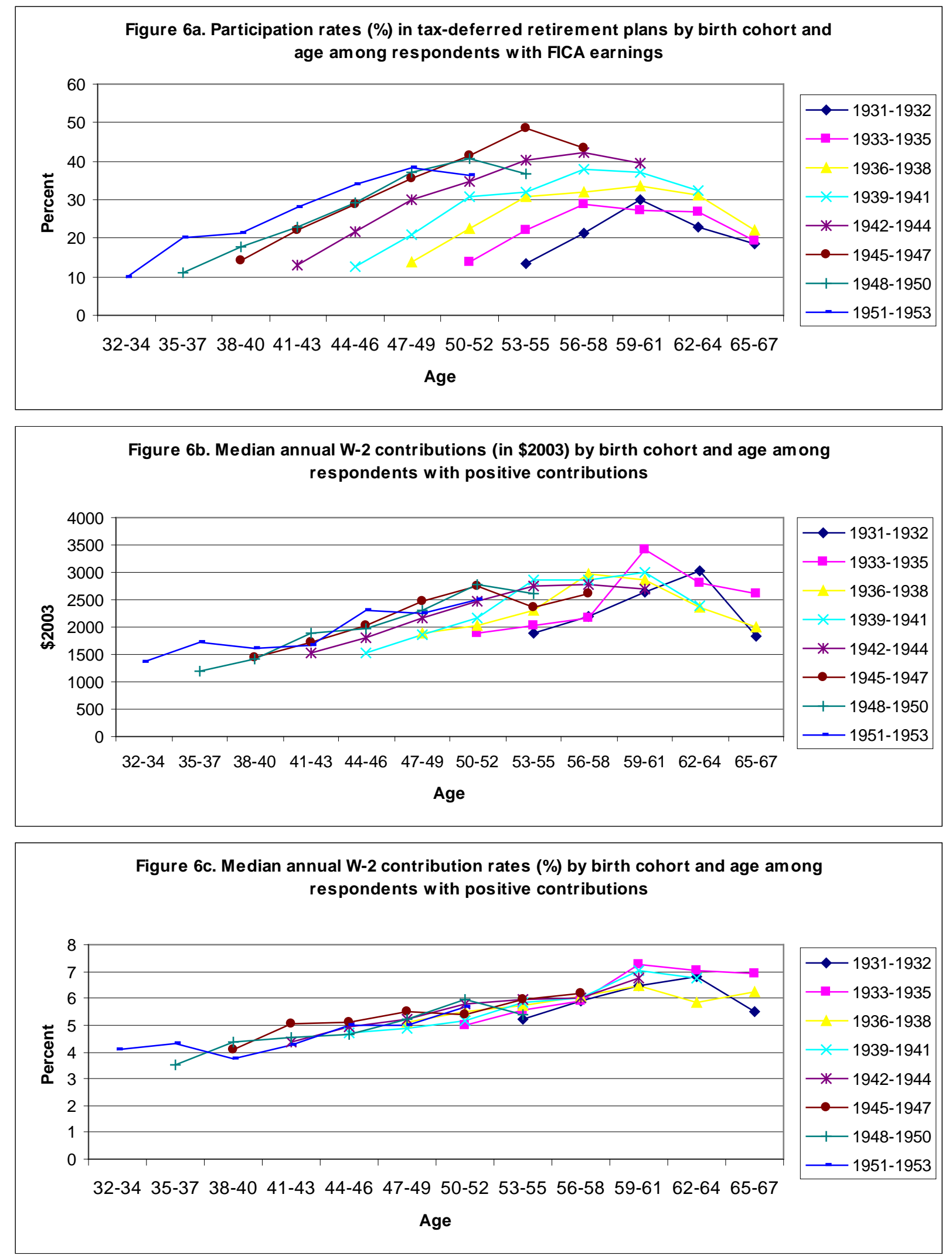
Appendix Table 1. Sample sizes of consenters and nonconsenters in the HRS,WB, and EBB cohorts

\begin{tabular}{crrr}
\hline \hline & Total & \multicolumn{2}{c}{ Consenters $^{1}$} \\
\cline { 2 - 5 } & $\mathrm{N}$ & $\mathrm{N}$ & $\%$ \\
\hline HRS Cohort: born 1931-1941 & 10,303 & 8,101 & 79 \\
1992 consent & & 4,019 & \\
1998 consent & & 50 & \\
2004 consent & & 4032 & \\
WB Cohort: born 1942-1947 & 3,426 & 2,435 & 71 \\
1992 consent & & 438 & \\
1998 consent & & 1,061 & \\
2004 consent & & 936 & \\
& & & \\
1948-1953 & 3,504 & 1,863 & 53 \\
1992 consent & & 94 & \\
1998 consent & & 186 & \\
2004 consent & & 1583 & \\
& & & \\
\hline
\end{tabular}

Notes : Authors' calculations using data from the Health and Retirement Study and Social Security earnings records.

${ }^{1}$ Respondents and their spouses in the Health and Retirement Study were asked either in 1992, 1998, or 2004 to give permission to link their survey information with Social Security earnings records. 
Appendix Table 2. Maximum annual Social Security taxable earnings, tax-deferred contributions, national average wage, and mean and median FICA earnings of the HRS sample

\begin{tabular}{|c|c|c|c|c|c|c|}
\hline \multirow[b]{2}{*}{ Year } & \multirow{2}{*}{$\begin{array}{c}\text { Social Security } \\
\text { taxable earnings } \\
\text { maximum }(\$)^{1}\end{array}$} & \multirow{2}{*}{$\begin{array}{c}\text { Maximum } \\
\text { contribution } \\
\text { limits }(\$)^{2}\end{array}$} & \multirow{2}{*}{$\begin{array}{c}\text { Over } 50 \\
\text { Catch up } \\
\text { contribution } \\
\text { amount }(\$)^{2}\end{array}$} & \multirow{2}{*}{$\begin{array}{c}\text { National } \\
\text { Average } \\
\text { Wage }(\$)^{3}\end{array}$} & \multicolumn{2}{|c|}{$\begin{array}{l}\text { FICA earnings of the HRS } \\
\text { sample }^{4}\end{array}$} \\
\hline & & & & & Mean (\$) & Median (\$) \\
\hline 1984 & 37,800 & n.a. & --- & 16,135 & 19,205 & 16,100 \\
\hline 1985 & 39,600 & n.a. & --- & 16,822 & 20,148 & 16,700 \\
\hline 1986 & 42,000 & n.a. & --- & 17,322 & 21,201 & 17,500 \\
\hline 1987 & 43,800 & 7,000 & --- & 18,426 & 22,016 & 18,200 \\
\hline 1988 & 45,000 & 7,313 & --- & 19,334 & 23,136 & 18,800 \\
\hline 1989 & 48,000 & 7,627 & --- & 20,100 & 24,228 & 19,600 \\
\hline 1990 & 51,300 & 7,979 & --- & 21,028 & 24,832 & 20,000 \\
\hline 1991 & 53,400 & 8,475 & --- & 21,812 & 25,652 & 20,500 \\
\hline 1992 & 55,500 & 8,728 & --- & 22,935 & 27,696 & 22,262 \\
\hline 1993 & 57,600 & 8,994 & --- & 23,133 & 28,042 & 22,400 \\
\hline 1994 & 60,600 & 9,240 & --- & 23,754 & 28,463 & 22,400 \\
\hline 1995 & 61,200 & 9,240 & --- & 24,706 & 29,648 & 23,400 \\
\hline 1996 & 62,700 & 9,500 & --- & 25,914 & 30,160 & 23,400 \\
\hline 1997 & 65,400 & 9,500 & --- & 27,426 & 30,697 & 23,400 \\
\hline 1998 & 68,400 & 10,000 & --- & 28,861 & 30,808 & 22,900 \\
\hline 1999 & 72,600 & 10,000 & --- & 30,470 & 30,884 & 22,500 \\
\hline 2000 & 76,200 & 10,500 & --- & 32,155 & 31,158 & 22,300 \\
\hline 2001 & 80,400 & 10,500 & --- & 32,922 & 31,708 & 22,200 \\
\hline 2002 & 84,900 & 11,000 & 1,000 & 33,252 & 30,936 & 21,350 \\
\hline 2003 & 87,000 & 12,000 & 2,000 & 34,065 & 31,081 & 21,500 \\
\hline
\end{tabular}

${ }^{1}$ http://www.socialsecurity.gov/mystatement/maxtax.htm

${ }^{2}$ Internal Revenue Code; http://answers.google.com/answers/threadview/id/443399.html

${ }^{3}$ Sourse: http://mwww.ba.ssa.gov/OACT/COLA/AWI.html or Social Security Trustees Report 2005.

${ }^{4}$ Mean and median FICA earnings are for the HRS sample (i.e., respondents born between 1931-1953) for whom there is a matched SSA record. Monetary values are in nominal dollars. 
Appendix Table 3. Periods of analysis and year of data

\begin{tabular}{ccccc}
\hline \hline \multirow{2}{*}{ Consent Year } & $\begin{array}{c}\text { Earnings records } \\
\text { available }\end{array}$ & Period of & \multicolumn{2}{c}{ Tax-deferred contributions } \\
\cline { 4 - 5 } analysis & & Available & Derived \\
\hline 1992 consent & $1980-1991$ & $1984-1991$ & n.a & $1984-1991$ \\
1998 consent & $1978-1997$ & $1984-1997$ & $1990-1997$ & $1984-1989$ \\
2004 consent & $1978-2003$ & $1984-2003$ & $1990-2003$ & $1984-1989$ \\
\hline
\end{tabular}

Notes: See notes in Appendix Table A.

${ }^{1}$ Years used in this analysis.

Appendix Table 4: Age evolution of respondents in the Health and Retirement Study by cohort

\begin{tabular}{|c|c|c|c|c|c|c|c|c|c|c|}
\hline \multirow{2}{*}{ Cohort } & \multirow{2}{*}{ Birth Year } & \multicolumn{2}{|c|}{$\begin{array}{l}\text { Ages over the } \\
\text { period of study }\end{array}$} & \multicolumn{7}{|c|}{ Interview year } \\
\hline & & 1984 & 2003 & 1992 & 1994 & 1996 & 1998 & 2000 & 2002 & 2004 \\
\hline \multirow{2}{*}{ HRS } & 1931-1935 & $49-53$ & $68-72$ & $57-61$ & $59-63$ & $61-65$ & $63-67$ & $65-69$ & $67-71$ & $69-73$ \\
\hline & 1936-1941 & $43-48$ & $62-67$ & $51-56$ & $53-58$ & $55-60$ & $57-62$ & $59-64$ & $61-66$ & $63-68$ \\
\hline WB & 1942-1947 & $37-42$ & $56-61$ & & & & $51-56$ & 53-58 & $55-60$ & $57-62$ \\
\hline EBB & 1948-1953 & $31-36$ & $50-55$ & & & & & & & $51-56$ \\
\hline
\end{tabular}

Note : Numbers in each row indicate ages of three birth cohorts at each wave of the survey, as well as at the beginning and end of the period of analysis. 
Appendix Table 5. Earnings, participation rates, contributions and contribution rates, by cohort and selected characteristics

\begin{tabular}{|c|c|c|c|c|c|c|c|c|c|c|c|c|c|c|c|}
\hline \multirow{2}{*}{ Selected characeristics } & \multicolumn{3}{|c|}{$\begin{array}{l}\text { Number of respondents } \\
\text { with FICA Earnings }{ }^{1}\end{array}$} & \multicolumn{3}{|c|}{ Median FICA earnings $^{2}(\$)$} & \multicolumn{3}{|c|}{ Participation rate ${ }^{3}(\%)$} & \multicolumn{3}{|c|}{ Median contribution $^{4}(\$)$} & \multicolumn{3}{|c|}{$\begin{array}{c}\text { Median contribution } \\
\text { rate }^{4}(\%)\end{array}$} \\
\hline & $\begin{array}{l}\text { HRS } \\
1991 \\
\end{array}$ & $\begin{array}{l}\text { WB } \\
1997\end{array}$ & $\begin{array}{l}\text { EBB } \\
2003 \\
\end{array}$ & $\begin{array}{l}\text { HRS } \\
1991 \\
\end{array}$ & $\begin{array}{l}\text { WB } \\
1997\end{array}$ & $\begin{array}{l}\text { EBB } \\
2003 \\
\end{array}$ & $\begin{array}{l}\text { HRS } \\
1991 \\
\end{array}$ & $\begin{array}{l}\text { WB } \\
1997 \\
\end{array}$ & $\begin{array}{l}\text { EBB } \\
2003 \\
\end{array}$ & $\begin{array}{l}\text { HRS } \\
1991 \\
\end{array}$ & $\begin{array}{l}\text { WB } \\
1997 \\
\end{array}$ & $\begin{array}{l}\text { EBB } \\
2003 \\
\end{array}$ & $\begin{array}{l}\text { HRS } \\
1991 \\
\end{array}$ & $\begin{array}{l}\text { WB } \\
1997 \\
\end{array}$ & $\begin{array}{l}\text { EBB } \\
2003 \\
\end{array}$ \\
\hline $\begin{array}{l}\text { Total } \\
\text { Gender }\end{array}$ & 3233 & 1412 & 1159 & 29,025 & 31,223 & 29,800 & $31 \%$ & $41 \%$ & $37 \%$ & 2,295 & 2,760 & 2,500 & 5.5 & 5.8 & 5.5 \\
\hline Male & 1643 & 613 & 523 & 39,690 & 43,355 & 39,000 & $30 \%$ & $43 \%$ & $41 \%$ & 2,835 & 3,680 & 3,100 & 5.4 & 5.9 & 5.8 \\
\hline $\begin{array}{l}\text { Female } \\
\text { Race }\end{array}$ & 1590 & 799 & 636 & 29,025 & 24,265 & 24,000 & $32 \%$ & $40 \%$ & $33 \%$ & 1,755 & 2,185 & 1,700 & 5.6 & 5.6 & 5.1 \\
\hline $\begin{array}{l}\text { White } \\
\text { Non-white }\end{array}$ & $\begin{array}{c}2390 \\
840\end{array}$ & $\begin{array}{c}1094 \\
314\end{array}$ & $\begin{array}{l}818 \\
341\end{array}$ & $\begin{array}{l}31,725 \\
22,680\end{array}$ & $\begin{array}{l}34,558 \\
22,655\end{array}$ & $\begin{array}{l}35,300 \\
20,400\end{array}$ & $\begin{array}{l}34 \% \\
24 \%\end{array}$ & $\begin{array}{l}45 \% \\
28 \%\end{array}$ & $\begin{array}{l}42 \% \\
22 \%\end{array}$ & $\begin{array}{l}2,430 \\
1,485\end{array}$ & $\begin{array}{l}2,990 \\
1,380\end{array}$ & $\begin{array}{l}2,700 \\
1,550\end{array}$ & $\begin{array}{l}5.7 \\
5.0\end{array}$ & $\begin{array}{l}6.0 \\
4.3\end{array}$ & $\begin{array}{l}5.6 \\
4.3\end{array}$ \\
\hline Education & & & & & & & & & & & & & & & \\
\hline $\begin{array}{l}\text { HS graduate or less } \\
\text { Some college } \\
\text { College and above }\end{array}$ & $\begin{array}{c}1968 \\
649 \\
613\end{array}$ & $\begin{array}{l}680 \\
363 \\
365\end{array}$ & $\begin{array}{l}478 \\
346 \\
335\end{array}$ & $\begin{array}{l}23,828 \\
33,885 \\
51,030\end{array}$ & $\begin{array}{l}23,920 \\
31,280 \\
50,370\end{array}$ & $\begin{array}{l}20,400 \\
29,600 \\
49,400\end{array}$ & $\begin{array}{l}23 \% \\
35 \% \\
53 \%\end{array}$ & $\begin{array}{l}32 \% \\
47 \% \\
52 \%\end{array}$ & $\begin{array}{l}25 \% \\
39 \% \\
50 \%\end{array}$ & $\begin{array}{l}1,485 \\
2,160 \\
3,510\end{array}$ & $\begin{array}{l}1,840 \\
2,185 \\
4,715\end{array}$ & $\begin{array}{l}1,600 \\
1,500 \\
4,000\end{array}$ & $\begin{array}{l}5.2 \\
5.3 \\
5.9\end{array}$ & $\begin{array}{l}5.2 \\
5.3 \\
6.8\end{array}$ & $\begin{array}{l}5.1 \\
4.2 \\
6.6\end{array}$ \\
\hline Marrital status & & & & & & & & & & & & & & & \\
\hline Married & 2416 & 1067 & 810 & 29,903 & 32,430 & 31,750 & $31 \%$ & $43 \%$ & $40 \%$ & 2,295 & 2,990 & 2,900 & 5.7 & 6.0 & 5.9 \\
\hline Non-married & 704 & 282 & 347 & 25,515 & 27,198 & 24,300 & $32 \%$ & $33 \%$ & $28 \%$ & 2,025 & 2070 & 1,400 & 5.0 & 5.1 & 4.3 \\
\hline Earnings quartiles & & & & & & & & & & & & & & & \\
\hline 1 & 696 & 229 & 162 & 5,670 & 4,945 & 4,300 & $7 \%$ & $5 \%$ & $1 \%$ & 405 & $345^{\mathrm{a}}$ & $600^{\mathrm{a}}$ & 5.0 & $7.4^{\mathrm{a}}$ & $9.2^{\mathrm{a}}$ \\
\hline 2 & 785 & 342 & 256 & 19,845 & 18,688 & 14,450 & $22 \%$ & $27 \%$ & $17 \%$ & 945 & 805 & 800 & 4.9 & 4.8 & 4.2 \\
\hline 3 & 823 & 384 & 341 & 34,695 & 33,925 & 30,200 & $37 \%$ & $46 \%$ & $40 \%$ & 1,890 & 1,610 & 1,400 & 5.6 & 5.1 & 4.7 \\
\hline 4 & 929 & 457 & 400 & 60,750 & 62,215 & 59,850 & $51 \%$ & $65 \%$ & $61 \%$ & 4,050 & 4,715 & 4,800 & 5.8 & 6.4 & 6.2 \\
\hline Middle earning quintile & 650 & 292 & 244 & 26,595 & 24,380 & 21,300 & $28 \%$ & $40 \%$ & $30 \%$ & 1350 & 1265 & 850 & 5.1 & 5.0 & 4.9 \\
\hline Earnings levels (\$2003) & & & & & & & & & & & & & & & \\
\hline 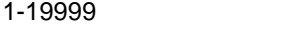 & 1100 & 448 & 392 & 9,450 & 10,638 & 10,400 & $11 \%$ & $12 \%$ & $9 \%$ & 675 & 690 & 600 & 4.9 & 5.2 & 3.5 \\
\hline 20000-29999 & 570 & 233 & 192 & 24,705 & 24,380 & 24,950 & $27 \%$ & $42 \%$ & $35 \%$ & 1,215 & 1,150 & 1,200 & 4.9 & 4.9 & 4.9 \\
\hline 30000-39999 & 462 & 195 & 154 & 34,965 & 34,845 & 35,300 & $36 \%$ & $46 \%$ & $45 \%$ & 1,890 & 1,610 & 1,600 & 5.2 & 5.0 & 4.8 \\
\hline 40000-49999 & 353 & 166 & 119 & 45,225 & 45,023 & 44,600 & $46 \%$ & $54 \%$ & $45 \%$ & 2,700 & 2,990 & 2,700 & 5.9 & 6.5 & 6.0 \\
\hline 50000-59999 & 269 & 120 & 102 & 54,000 & 65,683 & 54,650 & $45 \%$ & $58 \%$ & $53 \%$ & 3,375 & 3,163 & 2,700 & 6.1 & 5.6 & 5.2 \\
\hline 60000-69999 & 161 & 76 & 64 & 64,800 & 65,263 & 64,950 & $59 \%$ & $63 \%$ & $69 \%$ & 3,510 & 4,025 & 3,900 & 5.4 & 6.2 & 6.0 \\
\hline 70000-89999 & 174 & 88 & 60 & 77,018 & 78,603 & 76,650 & $62 \%$ & $70 \%$ & $70 \%$ & 4,523 & 5,635 & 6,000 & 5.9 & 6.9 & 7.4 \\
\hline $90000+$ & 144 & 86 & 74 & 114,818 & 115,748 & 118,800 & $47 \%{ }^{b}$ & $78 \%$ & $76 \%$ & 6,278 & 8,625 & 12,000 & 5.7 & 6.4 & 7.9 \\
\hline
\end{tabular}

Social Security records. Samples consist of respondents ages 50-55 in 1991 (HRS cohort), in 1997 (WB cohort) and 2003 (EBB cohort) for whom there is a matched SSA record. Monetary values are in $\$ 2003$.

${ }^{1}$ FICA earnings are earnings that are subject to the Social Security payroll tax.

${ }^{2}$ Estimates are among respondents with FICA earnings.

${ }^{3}$ The participation rate is the percentage of respondents with positive tax-deferred contributions among those with FICA earnings.

${ }^{4}$ The median contribution (or contribution rate) is calculated among respondents with positive tax-deferred contributions.

a Sample size is 30 or less.

${ }^{\mathrm{D}}$ This participation rate in tax-deferred plans is likely to be an underestimate of the true value. For respondents whose earnings subject to Medicare payroll tax are greater than their annual total compensation subject to federal income taxation, we calculate the amount of the tax-deferred contribution as the difference between the two values. For respondents whose Medicare earnings are less than their annual total compensation, approximately 27 percent of respondents, we cannot calculate their tax-deferred

contributions and therefore define them as non-participants. The remaining 26 percent of respondents in this group have Medicare earnings that are equal to total compensation and thus we infer zero tax-deferred contributions and non-participation. Participation rate of the WB and EB B cohorts are accurate because for these cohorts contributions are provided in the $\mathrm{W}-2$ records. 
Appendix Table 6. W-2 earnings distributions by cohort

\begin{tabular}{cccc}
\hline \hline $\begin{array}{c}\text { W-2 FICA earnings } \\
\text { categories }\end{array}$ & HRS 1991 & WB 1997 & EBB 2003 \\
\hline 1-9999 & 18.3 & 14.7 & 16.1 \\
$10000-19999$ & 15.7 & 17.0 & 17.8 \\
$20000-29999$ & 17.6 & 16.5 & 16.6 \\
$30000-39999$ & 14.3 & 13.8 & 13.3 \\
$40000-49999$ & 10.9 & 11.8 & 10.3 \\
$50000-59999$ & 8.3 & 8.5 & 8.8 \\
$60000-69999$ & 5.0 & 5.4 & 5.5 \\
$70000-89999$ & 5.4 & 6.2 & 5.2 \\
$90000+$ & 4.5 & 6.1 & 6.4 \\
\hline
\end{tabular}

Note: Authors' calculations using data from the Social Secuirty administrative records for Health and Retirement Study respondents. HRS sample is comprised of respondents ages 50-55 in 1991. Similarly, WB and EBB cohorts are comprised of respondents ages 50-55 in 1997 and 2003, respectively. FICA earnings are earnings that are subject to the Social Security payroll tax. 
Appendix Table 7. Earnings and tax-deferred contributions over time by cohort

\begin{tabular}{|c|c|c|c|c|c|c|c|c|c|c|c|c|c|c|c|c|c|c|c|c|}
\hline \multirow[b]{3}{*}{ Year } & \multicolumn{4}{|c|}{$\begin{array}{c}\text { Number of respondents with } \\
\text { FICA earnings }{ }^{1}\end{array}$} & \multicolumn{4}{|c|}{ Median FICA earnings $^{2}$ (\$) } & \multicolumn{4}{|c|}{ Participation rate ${ }^{3}(\%)$} & \multicolumn{4}{|c|}{ Median contribution $^{2}(\$)$} & \multicolumn{4}{|c|}{$\begin{array}{c}\text { Median contribution rate } \\
(\%)\end{array}$} \\
\hline & \multirow[b]{2}{*}{ All } & \multicolumn{3}{|c|}{ Cohort } & \multirow[b]{2}{*}{ All } & \multicolumn{3}{|c|}{ Cohort } & \multirow[b]{2}{*}{ All } & \multicolumn{3}{|c|}{ Cohort } & \multirow[b]{2}{*}{ All } & \multicolumn{3}{|c|}{ Cohort } & \multirow[b]{2}{*}{ All } & \multicolumn{3}{|c|}{ Cohort } \\
\hline & & HRS & WB & EBB & & HRS & WB & EBB & & HRS & WB & EBB & & HRS & WB & EBB & & HRS & WB & EBB \\
\hline 1984 & 8676 & 5628 & 1706 & 1342 & 28,497 & 29,736 & 27,435 & 24,426 & $10 \%$ & $10 \%$ & $10 \%$ & $8 \%$ & 1,593 & 1,770 & 1,416 & 1,416 & 4.9 & 5.1 & 4.6 & 4.1 \\
\hline 1985 & 8728 & 5635 & 1742 & 1351 & 28,557 & 29,754 & 27,873 & 25,308 & $13 \%$ & $13 \%$ & $14 \%$ & $10 \%$ & 1,710 & 1,710 & 1,539 & 1,197 & 4.8 & 5.0 & 4.3 & 3.9 \\
\hline 1986 & 8736 & 5648 & 1750 & 1338 & 29,400 & 30,408 & 28,392 & 26,040 & $16 \%$ & $16 \%$ & $17 \%$ & $13 \%$ & 1,848 & 2,016 & 1,512 & 1,344 & 5.0 & 5.3 & 4.4 & 4.3 \\
\hline 1987 & 8777 & 5625 & 1780 & 1372 & 29,484 & 30,456 & 28,674 & 26,649 & $20 \%$ & $20 \%$ & $20 \%$ & $17 \%$ & 1,782 & 1,944 & 1,539 & 1,458 & 4.9 & 5.0 & 4.6 & 4.1 \\
\hline 1988 & 8777 & 5614 & 1781 & 1382 & 29,328 & 30,108 & 28,392 & 26,520 & $21 \%$ & $22 \%$ & $22 \%$ & $19 \%$ & 1,872 & 2,028 & 1,716 & 1,560 & 5.1 & 5.3 & 5.0 & 4.3 \\
\hline 1989 & 8750 & 5564 & 1782 & 1404 & 29,204 & 29,949 & 29,204 & 26,224 & $24 \%$ & $25 \%$ & $26 \%$ & $21 \%$ & 1,788 & 1,937 & 1,639 & 1,490 & 5.0 & 5.4 & 4.8 & 4.5 \\
\hline 1990 & 8705 & 5497 & 1797 & 1411 & 28,200 & 28,764 & 28,482 & 25,944 & $26 \%$ & $27 \%$ & $26 \%$ & $25 \%$ & 1,833 & 1,974 & 1,833 & 1,410 & 5.1 & 5.4 & 5.0 & 4.2 \\
\hline 1991 & 8523 & 5340 & 1787 & 1396 & 27,675 & 28,080 & 27,945 & 26,393 & $29 \%$ & $30 \%$ & $29 \%$ & $22 \%$ & 2,160 & 2,295 & 2,160 & 1,620 & 5.4 & 5.7 & 5.2 & 4.1 \\
\hline 1992 & 5713 & 2882 & 1486 & 1345 & 29,164 & 29,737 & 30,654 & 26,855 & $29 \%$ & $30 \%$ & $31 \%$ & $24 \%$ & 2,620 & 2,882 & 2,489 & 1,965 & 5.3 & 5.9 & 5.3 & 4.4 \\
\hline 1993 & 5651 & 2817 & 1491 & 1343 & 28,448 & 28,321 & 29,337 & 27,305 & $29 \%$ & $29 \%$ & $33 \%$ & $26 \%$ & 2,540 & 2,921 & 2,413 & 1,905 & 5.5 & 5.9 & 5.5 & 4.5 \\
\hline 1994 & 5595 & 2764 & 1479 & 1352 & 27,776 & 26,784 & 30,008 & 26,908 & $31 \%$ & $30 \%$ & $35 \%$ & $29 \%$ & 2,604 & 3,100 & 2,480 & 1,984 & 5.6 & 6.1 & 5.6 & 4.4 \\
\hline 1995 & 5388 & 2591 & 1449 & 1348 & 28,314 & 26,983 & 30,674 & 27,830 & $33 \%$ & $32 \%$ & $37 \%$ & $31 \%$ & 2,662 & 2,904 & 2,662 & 2,057 & 5.6 & 6.1 & 5.8 & 4.7 \\
\hline 1996 & 5217 & 2464 & 1413 & 1340 & 27,378 & 24,804 & 31,005 & 28,080 & $35 \%$ & $32 \%$ & $40 \%$ & $34 \%$ & 2,574 & 2,808 & 2,691 & 1,989 & 5.8 & 6.3 & 5.9 & 4.9 \\
\hline 1997 & 5097 & 2345 & 1412 & 1340 & 26,910 & 23,920 & 31,223 & 28,405 & $35 \%$ & $32 \%$ & $41 \%$ & $35 \%$ & 2,645 & 2,875 & 2,760 & 2,300 & 5.9 & 6.3 & 5.8 & 5.1 \\
\hline 1998 & 4049 & 2158 & 676 & 1215 & 25,877 & 22,261 & 28,589 & 29,832 & $35 \%$ & $32 \%$ & $43 \%$ & $36 \%$ & 2,712 & 2,825 & 2,599 & 2,486 & 5.9 & 6.5 & 5.8 & 5.1 \\
\hline 1999 & 3899 & 2021 & 668 & 1210 & 24,750 & 19,360 & 28,270 & 30,195 & $35 \%$ & $31 \%$ & $43 \%$ & $38 \%$ & 2,640 & 2,640 & 2,640 & 2,695 & 6.0 & 6.7 & 6.0 & 5.3 \\
\hline 2000 & 3772 & 1896 & 652 & 1224 & 23,861 & 17,869 & 27,446 & 30,067 & $35 \%$ & $29 \%$ & $45 \%$ & $39 \%$ & 2,568 & 2,568 & 2,568 & 2,461 & 6.0 & 6.7 & 6.0 & 5.3 \\
\hline 2001 & 3573 & 1747 & 622 & 1204 & 23,088 & 16,640 & 27,768 & 30,420 & $35 \%$ & $28 \%$ & $45 \%$ & $39 \%$ & 2,496 & 2,392 & 2,496 & 2,496 & 6.0 & 6.4 & 6.1 & 5.3 \\
\hline 2002 & 3330 & 1551 & 604 & 1175 & 21,777 & 14,280 & 26,571 & 29,478 & $34 \%$ & $27 \%$ & $45 \%$ & $38 \%$ & 2,448 & 2,040 & 2,652 & 2,550 & 6.1 & 6.3 & 6.4 & 5.6 \\
\hline 2003 & 3127 & 1395 & 573 & 1159 & 21,500 & 13,600 & 25,900 & 29,800 & $32 \%$ & $23 \%$ & $41 \%$ & $37 \%$ & 2,400 & 2,200 & 2,663 & 2,500 & 6.0 & 6.6 & 6.2 & 5.5 \\
\hline
\end{tabular}

Notes: Authors' calculations using data from the Social Secuirty administrative records of respondents in the Health and Retirement Study who gave consents to release their Social

Security records. The sample consists of respondents in the HRS born 1931-1953 (HRS, WB and EBB cohorts) for whom there is a matched SSA record. Monetary values are in \$2003.

${ }^{1}$ FICA earnings are earnings that are subject to the Social Security payroll tax.

${ }^{2}$ Estimates are among respondents with FICA earnings.

${ }^{3}$ The participation rate for each year is the percentage of respondents with positive tax-deferred contributions among those with FICA earnings.

${ }^{4}$ The median contribution (or contribution rate) for each year is calculated among respondents with positive tax-deferred contributions. 
Appendix Table 8. Number of respondents with FICA earnings, participation rate, median contribution, median contribution rate, by earnings quartiles and year

\begin{tabular}{|c|c|c|c|c|c|c|c|c|c|c|c|c|c|c|c|c|}
\hline \multirow[b]{3}{*}{ Year } & \multirow{2}{*}{\multicolumn{4}{|c|}{$\begin{array}{c}\begin{array}{c}\text { Number of respondents with } \\
\text { FICA earnings }\end{array} \\
\text { Quartiles }\end{array}$}} & \multicolumn{4}{|c|}{ Participation rate ${ }^{2}(\%)$} & \multicolumn{4}{|c|}{ Median contribution $^{3}(\$)$} & \multicolumn{4}{|c|}{ Median contribution rate ${ }^{3}(\%)$} \\
\hline & & & & & \multicolumn{4}{|c|}{ Quartiles } & \multicolumn{4}{|c|}{ Quartiles } & \multicolumn{4}{|c|}{ Quartiles } \\
\hline & 1 & 2 & 3 & 4 & 1 & 2 & 3 & 4 & 1 & 2 & 3 & 4 & 1 & 2 & 3 & 4 \\
\hline 1984 & 2154 & 2204 & 2192 & 2126 & 2.7 & 9.0 & 14.9 & 12.2 & 531 & 1,062 & 1,859 & 2,478 & 5.5 & 4.8 & 5.0 & 4.4 \\
\hline 1985 & 2132 & 2208 & 2208 & 2180 & 3.1 & 11.5 & 18.2 & 18.9 & 513 & 1,026 & 1,881 & 2,736 & 5.6 & 4.7 & 4.9 & 4.7 \\
\hline 1986 & 2140 & 2212 & 2199 & 2185 & 4.3 & 14.2 & 20.8 & 23.2 & 504 & 1,008 & 1,848 & 2,856 & 5.1 & 4.8 & 5.1 & 5.0 \\
\hline 1987 & 2105 & 2215 & 2234 & 2223 & 4.8 & 17.3 & 27.5 & 28.3 & 486 & 972 & 1,782 & 2,916 & 5.4 & 4.6 & 4.8 & 5.0 \\
\hline 1988 & 2081 & 2215 & 2235 & 2246 & 4.9 & 19.2 & 29.7 & 30.7 & 468 & 1,092 & 2,028 & 3,120 & 5.1 & 4.8 & 5.0 & 5.1 \\
\hline 1989 & 2067 & 2190 & 2243 & 2250 & 5.6 & 21.2 & 32.9 & 35.2 & 447 & 1,043 & 1,937 & 3,129 & 5.0 & 4.8 & 5.0 & 5.3 \\
\hline 1990 & 1997 & 2201 & 2236 & 2272 & 5.9 & 20.5 & 34.7 & 41.4 & 423 & 987 & 1,833 & 3,384 & 5.9 & 4.7 & 4.9 & 5.5 \\
\hline 1991 & 1933 & 2169 & 2199 & 2225 & 6.3 & 21.0 & 34.1 & 50.4 & 405 & 945 & 1,890 & 3,915 & 5.6 & 4.8 & 5.3 & 5.9 \\
\hline 1992 & 1212 & 1434 & 1527 & 1543 & 4.6 & 18.6 & 32.2 & 53.7 & 524 & 917 & 1,834 & 4,192 & 7.7 & 4.5 & 5.2 & 5.8 \\
\hline 1993 & 1204 & 1393 & 1518 & 1538 & 5.7 & 18.5 & 32.0 & 54.2 & 635 & 889 & 1,778 & 4,572 & 7.6 & 4.7 & 5.1 & 6.0 \\
\hline 1994 & 1181 & 1389 & 1497 & 1532 & 5.2 & 19.1 & 34.2 & 58.1 & 372 & 868 & 1,736 & 4,464 & 6.3 & 4.7 & 5.1 & 6.1 \\
\hline 1995 & 1144 & 1356 & 1417 & 1473 & 5.1 & 21.0 & 39.0 & 60.3 & 484 & 847 & 1,815 & 4,598 & 7.1 & 4.6 & 5.2 & 6.1 \\
\hline 1996 & 1106 & 1306 & 1385 & 1427 & 5.8 & 23.1 & 40.9 & 62.4 & 585 & 936 & 1,755 & 4,329 & 7.9 & 4.8 & 5.3 & 6.2 \\
\hline 1997 & 1101 & 1262 & 1343 & 1392 & 5.4 & 23.9 & 41.7 & 63.4 & 345 & 920 & 1,725 & 4,830 & 5.9 & 5.0 & 5.2 & 6.3 \\
\hline 1998 & 949 & 993 & 1048 & 1059 & 6.4 & 23.1 & 42.6 & 65.0 & 339 & 904 & 1,808 & 4,859 & 7.7 & 4.8 & 5.3 & 6.6 \\
\hline 1999 & 925 & 966 & 990 & 1018 & 7.0 & 22.4 & 43.8 & 63.9 & 330 & 880 & 1,760 & 4,950 & 6.5 & 5.0 & 5.3 & 6.7 \\
\hline 2000 & 906 & 623 & 960 & 983 & 5.7 & 22.2 & 45.9 & 64.7 & 428 & 856 & 1,712 & 4,815 & 7.3 & 5.1 & 5.2 & 6.7 \\
\hline 2001 & 858 & 893 & 892 & 930 & 6.5 & 23.0 & 43.6 & 63.0 & 208 & 832 & 1,664 & 5,096 & 6.0 & 5.1 & 5.1 & 6.9 \\
\hline 2002 & 815 & 827 & 828 & 860 & 7.7 & 21.9 & 42.6 & 61.9 & 204 & 714 & 1,632 & 5,100 & 6.3 & 5.0 & 5.2 & 7.0 \\
\hline 2003 & 768 & 779 & 780 & 800 & 3.9 & 18.7 & 41.8 & 60.5 & 300 & 850 & 1,500 & 5,300 & 6.5 & 5.6 & 5.1 & 7.2 \\
\hline
\end{tabular}

Notes : Authors' calculations using data from the Social Secuirty administrative records of respondents in the Health and Retirement Study who gave consents to release their Social Security records. The sample consists of respondents in the HRS born 1931-1953 (HRS, WB and EBB cohorts) for whom there is a matched SSA record. Monetary values are in $\$ 2003$.

${ }^{1}$ FICA earnings are earnings that are subject to the Social Security payroll tax.

${ }^{2}$ The participation rate for each year is the percentage of respondents with positive W-2 tax-deferred contributions among those with FICA earnings.

${ }^{3}$ The median contribution (or contribution rate) for each year is calculated among respondents with positive tax-deferred contributions. 
Appendix Table 9: Participation rate, median contribution, and median contribution rate by age for selected years

\begin{tabular}{|c|c|c|c|c|c|c|c|c|c|c|c|c|}
\hline \multirow{2}{*}{ Age } & \multicolumn{4}{|c|}{ Particiaption rate ${ }^{1}(\%)$} & \multicolumn{4}{|c|}{ Median contribution $^{2}$ (\$) } & \multicolumn{4}{|c|}{ Median contribution rate ${ }^{2}(\%)$} \\
\hline & 1985 & 1991 & 1997 & 2003 & 1985 & 1991 & 1997 & 2003 & 1985 & 1991 & 1997 & 2003 \\
\hline $32-34$ & 9.8 & & & & 1368 & & & & 4.1 & & & \\
\hline $35-37$ & 11.0 & & & & 1197 & & & & 3.5 & & & \\
\hline $38-40$ & 14.4 & 21.2 & & & 1432 & 1620 & & & 4.1 & 3.7 & & \\
\hline $41-43$ & 12.9 & 22.8 & & & 1539 & 1890 & & & 4.3 & 4.5 & & \\
\hline $44-46$ & 12.6 & 29.0 & 33.8 & & 1539 & 2025 & 2300 & & 4.7 & 5.1 & 5.0 & \\
\hline $47-49$ & 14.0 & 30.0 & 37.0 & & 1881 & 2160 & 2300 & & 5.1 & 5.2 & 5.2 & \\
\hline $50-52$ & 13.8 & 30.9 & 41.6 & 36.2 & 1881 & 2160 & 2760 & 2500 & 5.0 & 5.2 & 5.4 & 5.6 \\
\hline $53-55$ & 13.3 & 30.9 & 40.2 & 36.9 & 1881 & 2295 & 2760 & 2600 & 5.2 & 5.8 & 6.0 & 5.4 \\
\hline $56-58$ & & 28.7 & 37.8 & 43.5 & & 2160 & 2875 & 2625 & & 5.9 & 6.0 & 6.2 \\
\hline $59-61$ & & 29.9 & 33.7 & 39.4 & & 2633 & 2875 & 2700 & & 6.5 & 6.5 & 6.8 \\
\hline $62-64$ & & & 26.8 & 32.3 & & & 2718 & 2400 & & & 7.0 & 6.7 \\
\hline $65-67$ & & & 18.5 & 22.2 & & & 1740 & 2000 & & & 5.5 & 6.3 \\
\hline $68-70$ & & & & 13.3 & & & & 1800 & & & & 6.1 \\
\hline $71-73$ & & & & 7.0 & & & & $1100^{\mathrm{a}}$ & & & & $8.0^{\mathrm{a}}$ \\
\hline
\end{tabular}

Notes: Authors' calculations using data from the Social Secuirty administrative records of respondents in the Health and Retirement Study who gave consents to release their Social Security records. The sample consists of respondents in the HRS born 1931-1953 (HRS, WB and EBB cohorts) for whom there is a matched SSA record. Monetary values are in \$2003.

${ }^{1}$ The participation rate for each age group is the percentage of respondents with positive tax-deferred contributions among those with FICA earnings. FICA earnings are earnings that are subject to the Social Security payroll tax.

${ }^{2}$ The median contribution (or contribution rate) for each age group is calculated among respondents with positive tax-deferred contributions.

${ }^{a}$ Sample size is 30 or less. 
Appendix Table 10a. Participation rate ${ }^{1}(\%)$ in tax-deferred retirement accounts by age and birth cohort among respondents with FICA earnings

\begin{tabular}{|c|c|c|c|c|c|c|c|c|}
\hline \multirow[b]{2}{*}{ Age } & \multicolumn{8}{|c|}{ Birth cohort } \\
\hline & $\begin{array}{r}1931- \\
1932\end{array}$ & $\begin{array}{r}1933- \\
1935\end{array}$ & $\begin{array}{r}1936- \\
1938\end{array}$ & $\begin{array}{r}1939- \\
1941\end{array}$ & $\begin{array}{r}1942- \\
1944\end{array}$ & $\begin{array}{r}1945- \\
1947\end{array}$ & $\begin{array}{r}1948- \\
1950\end{array}$ & $\begin{array}{r}1951- \\
1953 \\
\end{array}$ \\
\hline $32-34$ & & & & & & & & 9.8 \\
\hline $35-37$ & & & & & & & 11.0 & 20.2 \\
\hline $38-40$ & & & & & & 14.4 & 17.7 & 21.2 \\
\hline $41-43$ & & & & & 12.9 & 22.2 & 22.7 & 28.0 \\
\hline $44-46$ & & & & 12.6 & 21.8 & 29.0 & 29.3 & 33.8 \\
\hline $47-49$ & & & 14.0 & 21.1 & 29.9 & 35.7 & 37.0 & 38.2 \\
\hline $50-52$ & & 13.8 & 22.5 & 30.9 & 34.6 & 41.6 & 40.6 & 36.2 \\
\hline $53-55$ & 13.3 & 22.3 & 30.9 & 31.9 & 40.2 & 48.7 & 36.9 & \\
\hline $56-58$ & 21.5 & 28.7 & 31.9 & 37.8 & 42.4 & 43.5 & & \\
\hline $59-61$ & 29.9 & 27.3 & 33.7 & 37.0 & 39.4 & & & \\
\hline $62-64$ & 23.0 & 26.8 & 31.1 & 32.4 & & & & \\
\hline $65-67$ & 18.5 & 19.5 & 22.2 & & & & & \\
\hline $68-70$ & 13.0 & 13.4 & & & & & & \\
\hline $71-73$ & 7.0 & & & & & & & \\
\hline
\end{tabular}

Notes : Authors' calculations using data from the Social Secuirty administrative records of respondents in the Health and Retirement Study who gave consents to release their Social Security records. The sample consists of respondents in the HRS born 1931-1953 (HRS, WB and EBB cohorts) for whom there is a matched SSA record. The initial age in each column is the age of respondents in the specific birth cohort in 1985.

${ }^{1}$ The participation rate is the percentage of respondents with positive tax-deferred contributions in W-2 records among those with FICA earnings. FICA earnings are earnings that are subject to the Social Security payroll tax. 
Table 10b. Median annual W-2 contribution ${ }^{1}$ (in \$2003) by age and birth cohort among respondents with positive contributions

\begin{tabular}{|c|c|c|c|c|c|c|c|c|}
\hline \multirow[b]{2}{*}{ Age } & \multicolumn{8}{|c|}{ Birth cohort } \\
\hline & $\begin{array}{r}1931- \\
1932 \\
\end{array}$ & $\begin{array}{r}1933- \\
1935\end{array}$ & $\begin{array}{r}1936- \\
1938\end{array}$ & $\begin{array}{r}1939- \\
1941\end{array}$ & $\begin{array}{r}1942- \\
1944\end{array}$ & $\begin{array}{r}1945- \\
1947\end{array}$ & $\begin{array}{r}1948- \\
1950\end{array}$ & $\begin{array}{r}1951- \\
1953\end{array}$ \\
\hline $32-34$ & & & & & & & & 1368 \\
\hline $35-37$ & & & & & & & 1197 & 1716 \\
\hline $38-40$ & & & & & & 1432 & 1404 & 1620 \\
\hline $41-43$ & & & & & 1539 & 1716 & 1890 & 1674 \\
\hline $44-46$ & & & & 1539 & 1794 & 2025 & 1984 & 2300 \\
\hline $47-49$ & & & 1881 & 1872 & 2160 & 2480 & 2300 & 2247 \\
\hline $50-52$ & & 1881 & 2028 & 2160 & 2480 & 2760 & 2782 & 2500 \\
\hline $53-55$ & 1881 & 2028 & 2295 & 2852 & 2760 & 2354 & 2600 & \\
\hline $56-58$ & 2184 & 2160 & 2976 & 2875 & 2782 & 2625 & & \\
\hline $59-61$ & 2633 & 3410 & 2875 & 2996 & 2700 & & & \\
\hline $62-64$ & 3038 & 2818 & 2354 & 2400 & & & & \\
\hline $65-67$ & 1840 & 2622 & 2000 & & & & & \\
\hline $68-70$ & $1712^{\mathrm{a}}$ & 1800 & & & & & & \\
\hline $71-73$ & $1100^{a}$ & & & & & & & \\
\hline
\end{tabular}

Notes: Authors' calculations using data from the Social Secuirty administrative records of respondents in the Health and Retirement Study who gave consents to release their Social Security records. The sample consists of respondents in the HRS born 1931-1953 (HRS, WB and EBB cohorts) for whom there is a merged SSA record. Monetary values are in \$2003. The initial age in each column is the age of respondents in the specific birth cohort in 1985.

${ }^{1}$ The median annual contribution is calculated among respondents with positive W-2 tax-deferred contributions.

a Sample size is 30 or less 
Table 10c. Median annual W-2 contribution rate $^{1}(\%)$ by age and birth cohort among respondents with positive contributions

\begin{tabular}{|c|c|c|c|c|c|c|c|c|}
\hline \multirow[b]{2}{*}{ Age } & \multicolumn{8}{|c|}{ Birth cohort } \\
\hline & $\begin{array}{r}1931- \\
1932\end{array}$ & $\begin{array}{r}1933- \\
1935\end{array}$ & $\begin{array}{r}1936- \\
1938\end{array}$ & $\begin{array}{r}1939- \\
1941\end{array}$ & $\begin{array}{r}1942- \\
1944\end{array}$ & $\begin{array}{r}1945- \\
1947\end{array}$ & $\begin{array}{r}1948- \\
1950\end{array}$ & $\begin{array}{r}1951- \\
1953\end{array}$ \\
\hline $32-34$ & & & & & & & & 4.1 \\
\hline $35-37$ & & & & & & & 3.5 & 4.3 \\
\hline $38-40$ & & & & & & 4.1 & 4.4 & 3.7 \\
\hline $41-43$ & & & & & 4.3 & 5.0 & 4.5 & 4.3 \\
\hline $44-46$ & & & & 4.7 & 5.0 & 5.1 & 4.7 & 5.0 \\
\hline $47-49$ & & & 5.1 & 4.9 & 5.2 & 5.5 & 5.2 & 5.0 \\
\hline $50-52$ & & 5.0 & 5.5 & 5.2 & 5.8 & 5.4 & 5.9 & 5.6 \\
\hline $53-55$ & 5.2 & 5.5 & 5.8 & 5.8 & 6.0 & 5.9 & 5.4 & \\
\hline $56-58$ & 5.9 & 5.9 & 6.1 & 6.0 & 6.0 & 6.2 & & \\
\hline $59-61$ & 6.5 & 7.2 & 6.5 & 7.0 & 6.8 & & & \\
\hline $62-64$ & 6.8 & 7.0 & 5.8 & 6.7 & & & & \\
\hline $65-67$ & 5.5 & 6.9 & 6.3 & & & & & \\
\hline $68-70$ & $8.1^{\mathrm{a}}$ & 6.1 & & & & & & \\
\hline $71-73$ & $8.0^{\mathrm{a}}$ & & & & & & & \\
\hline \multicolumn{9}{|c|}{$\begin{array}{l}\text { Notes : Authors' calculations using data from the Social Secuirty administrative records of respondents } \\
\text { in the Health and Retirement Study who gave consents to release their Social Security records. The } \\
\text { sample consists of respondents in the HRS born 1931-1953 (HRS, WB and EBB cohorts) for whom } \\
\text { there is a matched SSA record. The initial age in each column is the age of respondents in the specific } \\
\text { birth cohort in } 1985 .\end{array}$} \\
\hline \multicolumn{9}{|c|}{$\begin{array}{l}{ }^{1} \text { The median annual contribution rate is calculated among respondents with positive } \mathrm{W}-2 \text { tax-deferred } \\
\text { contributions. }\end{array}$} \\
\hline a Sample & 30 or le & & & & & & & \\
\hline
\end{tabular}

